INSTITUTO DE PESQUISAS ENERGÉTICAS E NUCLEARES

Autarquia associada à Universidade de São Paulo

\title{
REMEDIAÇÃO DE SOLOS CONTAMINADOS COM AGROTÓXICOS PELO TRATAMENTO COM RADIAÇÃO GAMA
}

JANILSON SILVA SANTOS

Dissertação apresentada como parte dos requisitos para obtenção do grau de Mestre em Ciências na área de Tecnologia Nuclear - Aplicações

Orientadora:

Dra Celina Lopes Duarte

SÃO PAULO

2009 
Posso todas as coisas naquele que me fortalece.

Fil. 4:13 


\section{AGRADECIMENTOS}

Esta dissertação pôde tornar-se realidade graças, principalmente a Deus e apoio de diversas pessoas. Desejo agradecer:

- À Dra. Celina Lopes Duarte, por todo apoio, confiança, paciência e ajuda;

- À Dra. lara Camargo, por me conceder o seu laboratório para análises e correções sugeridas;

- À Dra. Ivone Mulako Sato e ao Dr Marcos Scapin, por realizar os ensaios dos óxidos metálicos;

- Aos MSc. Manoel Nunes Mori e Hiroshi Oikawa pela ajuda com as análises cromatográficas;

- Ao IPEN pela oportunidade e estrutura oferecida para o desenvolvimento do trabalho e

- A toda minha família. 


\section{REMEDIAÇÃO DE SOLOS CONTAMINADOS COM AGROTÓXICOS PELO TRATAMENTO COM RADIAÇÃO GAMA}

\section{JANILSON SILVA SANTOS RESUMO}

O descarte de embalagens plásticas de agrotóxicos de forma indevida pode causar sérios problemas de contaminação do solo, principalmente no Brasil, que está em terceiro lugar no mercado de consumo de agrotóxicos. É importante conhecer os processos que afetam o transporte e a potencialidade de contaminação dos agrotóxicos no solo e águas subterrâneas e desenvolver estratégias de remediação. Em virtude de seu impacto na remediação de solos a sorção tem sido muito estudada em pesquisas que envolvam a interação soloagrotóxico. O principal objetivo deste estudo é avaliar a transferência de agrotóxicos de uma mistura de embalagens comerciais de polietileno de alta densidade, PEAD, usados na agricultura, para o solo e sua remoção pelo tratamento com radiação gama. Duas amostras de solos, um do tipo textura média e o outro de textura muito argilosa, foram expostos à embalagens contaminadas com uma mistura dos agrotóxicos metomil, dimetoato, carbofuram, metildation, triazina, triazofos, atrazina, ametrina, endosulfan, clorpirifós, triazofós e trifluralin. A lixiviação dos agrotóxicos das embalagens para os solos foi homogênea, com pequenas variações, considerando um trabalho experimental. A radiação ionizante apresentou eficiência elevada na degradação dos agrotóxicos de ambos os solos, mas é dependente das características físico-químicas do solo contaminado. A eficiência maior foi obtida para o solo com concentrações maiores de matéria orgânica e umidade. No caso do solo de textura média, a eficiência foi mais elevada, com uma dose absorvida de $20 \mathrm{kGy}$ a totalidade dos agrotóxicos foi removida em todas as camadas. No caso do solo argiloso foi necessário uma dose absorvida maior que 30 kGy para remover a totalidade dos agrotóxicos presentes. 


\section{REMEDIATION OF SOIL CONTAMINATED WITH PESTICIDES \\ BY TREATMENT WITH GAMMA RADIATION}

\section{JANILSON SILVA SANTOS \\ ABSTRACT}

The discharge of empty plastic packaging of pesticides can be an environmental concern mainly by soil contamination. Nowadays, Brazil figures in third place among the leading world pesticide markets. An understanding of the processes that affect the transport and fate of pesticides is crucial to assess their potential for contamination of soil and groundwater, and to develop efficient and costeffective site management and soil remediation strategies. Due to its impact on soil remediation has made sorption a major topic of research on soil-pesticide interactions. The main objective of this study is the evaluation of the pesticides transferring from contaminated mixture of commercial polymeric packing of highdensity polyethylene, HDPE, used in agriculture to soil and their removal by gamma irradiation. Two soil samples of argyles compositions and media composition were exposed to a mixture of commercial polymeric packing contaminated with the pesticides methomyl, dimethoate, carbofuran, methydathion, triazine, thiophos, atrazyne, ametryne, endosulfan, chlorpyrifos, thriazophos and trifluralin. The pesticides leaching from packaging to soil was homogeneous considering a experimental research. The radiation treatment presented high efficiency on removal pesticides from both soil, but it depends on the physical-chemical characteristics of the contaminated soil. The higher efficiency was obtained in soils with higher organic material and humidity. The higher efficiency was obtained for the medium texture soil, with 20 kGy all

present pesticides were removed in all layers. In the case of argyles texture soil, it was necessary a $30 \mathrm{kGy}$ to remove the totality of present pesticides. 


\section{Sumário}

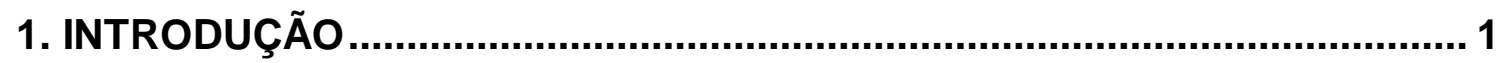

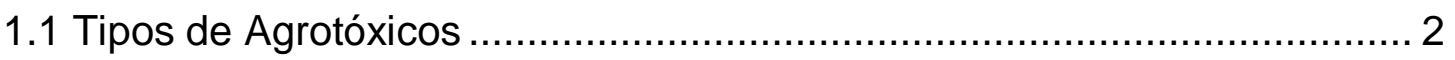

1.1.1 Consumo de agrotóxicos no Brasil.................................................. 4

1.1.2 O Problema das Embalagens de Agrotóxicos................................... 5

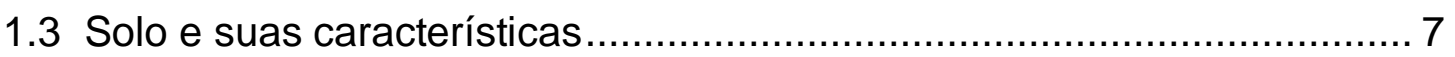

1.3.1 Contaminação de Solos por Agrotóxicos ………........................... 10

1.3.2 Fatores que influenciam a absorção de agrotóxicos pelo solo..........12

1.3.3 Técnicas de Remediação de Solos ............................................... 16

1.4 Aplicação da Radiação Ionizante na Degradação de Agrotóxicos ........... 18

1.4.1 Fontes de Radiação Ionizante ................................................... 21

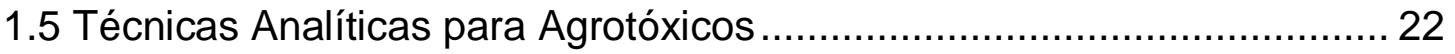

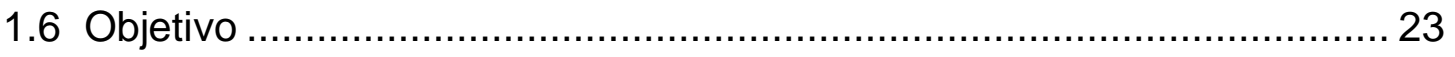

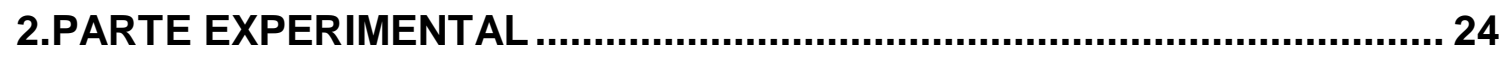

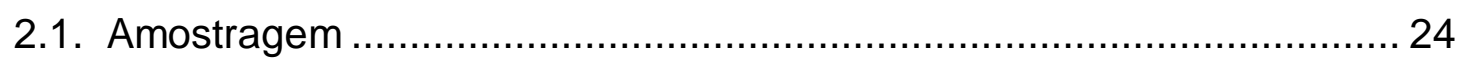

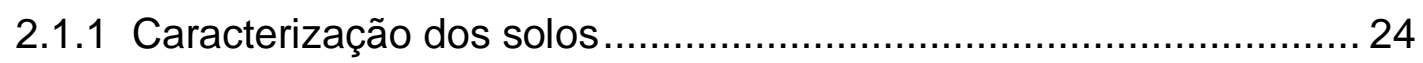

2.2. Montagem das colunas e lixiviação do solo.........................................26

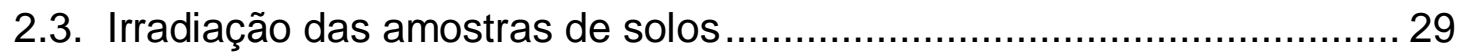

2.4. Análise de agrotóxicos em amostras de solos.................................... 30

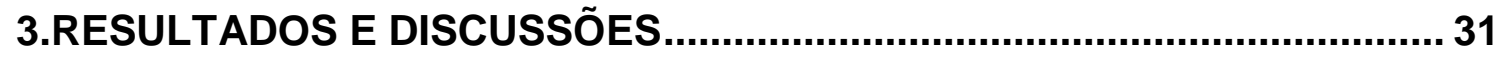

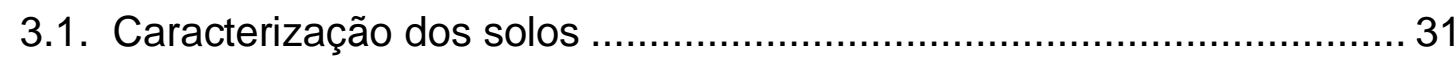

3.2. Caracterização da Contaminação …………..................................... 34

3.2.1. Distribuição dos agrotóxicos nas camadas de solos ........................ 39

3.2.2. Distribuição dos metais nas camadas de solos ............................. 43

3.3. Avaliação da eficiência do processamento por radiação gama ........... 46

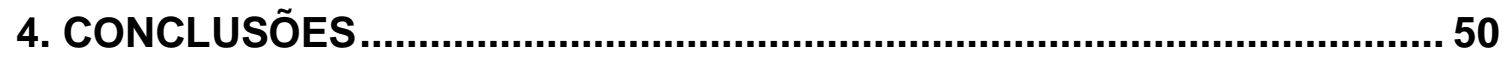

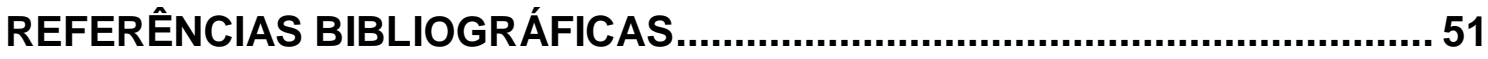




\section{INTRODUÇÃO}

Os agrotóxicos podem ser definidos como quaisquer produtos de natureza biológica, física ou química que tem a finalidade de exterminar pragas ou doenças que a ataquem as culturas agrícolas e podem ser ${ }^{(55,58)}$ :

- Inseticidas ou praguicidas: Combatem os insetos em geral;

- Fungicidas: Combatem os fungos;

- Herbicidas: Atacam as plantas invasoras ou daninhas.

Os agrotóxicos são largamente utilizados na agricultura, para defender as plantações de pragas. Estes produtos químicos estão no Brasil desde a década de 60. A utilização dos agrotóxicos tem beneficiado o desenvolvimento das lavouras, já que impede a ação dos seres nocivos. Haja vista que a produção mundial de alimentos em geral, vem aumentando a cada ano e a utilização de agrotóxicos tornou-se quase irreversível pelo aumento demográfico e, conseqüentemente, a demanda por alimentos. Porém a má utilização destes compostos tem conseqüências devastadoras ao meio ambiente, animais silvestres e seres humanos causando doenças crônicas que levam até a morte ${ }^{(58)}$.

O uso de agrotóxicos se deve às necessidades de controle de pragas e doenças que atacam culturas de interesse agronômico, onde o controle químico e biológico ainda não é comercialmente viável. Este uso deveria idealmente ocorrer em condições controladas, isto é, que possibilitassem a produção agrícola e, ao mesmo tempo, mantivessem as condições do ambiente. Mas, muitas vezes não é assim que acontece e após aplicações sobre as plantações, o solo pode ser contaminado não intencionalmente.

O agrotóxico pode ser aplicado na cultura propriamente dita ou incorporado ao solo. A grande variação das fórmulas químicas estruturais encontradas nos agrotóxicos leva à multiplicidade de comportamento destas substâncias no solo. Considerando os possíveis destinos dos agrotóxicos após serem adicionados aos solos pode se citar a evaporação que leva à perda na 
atmosfera, sem nenhuma modificação química; a adsorção pelo solo; a perda por lixiviação, pois poderão adentrar ao solo sob forma líquida ou de solução; poderão ser submetidos a reações químicas na superfície ou interior do solo e poderão também ser desagregados pelos microorganismos ${ }^{(55,58)}$.

\subsection{Tipos de Agrotóxicos}

Os agrotóxicos são divididos em inorgânicos e orgânicos. Os inorgânicos foram muito utilizados no passado, porém atualmente não representam mais do que $10 \%$ do total dos agrotóxicos em uso. São eles os produtos a base de arsênio e flúor e os compostos minerais que agem por contato, matando as pragas por asfixia, visto que os insetos respiram pela pele ${ }^{(6)}$.

Os agrotóxicos orgânicos compreendem os de origem vegetal e os sintéticos. Os primeiros, muito utilizados por alguma corrente da agroecologia, são de baixa toxicidade e de curta permanência no ambiente (ex. do opiretro extraído do timbó). Já os sintéticos, além de persistirem muitos anos nos ecossistemas, também trazem uma série de problemas à saúde dos seres humanos, o que torna seu uso proibido pelas correntes agroecológicas. Entre os agrotóxicos organo-sintéticos mais utilizados, pode-se citar ${ }^{(6)}$ :

\section{- Os clorados}

São os agrotóxicos compostos por um hidrocarboneto clorado que tem um ou mais anéis aromáticos. Embora sejam menos tóxicos (em termos de toxidade aguda, que provoca morte imediata) que outros organo-sintéticos, são também mais persistentes no ambiente e são metabolizados lentamente pelo organismo humano, causando efeitos patológicos em longo prazo. O agrotóxico organoclorado atua no sistema nervoso, interferindo nas transmissões dos impulsos nervosos. O famoso "DDT" (diclorodifeniltricloroetano) faz parte deste grupo; 


\section{- Os clorofosforados}

São os agrotóxicos que possuem um éster de ácido fosfórico e outros ácidos a base de fósforo e em um dos radicais da molécula possui também um ou mais átomo de cloro. Apresentam toxidez aguda, capazes de provocar morte imediata, atuando sobre a enzima fundamental do sistema nervoso, a colinesterase, que atua nas transmissões do impulso nervoso;

\section{- Os fosforados}

Os fosforados são formados por ésteres de ácidos fosfóricos (ex. dietilnitrofenil-fosforotionato). Considerando os agrotóxicos clorados e carbamatos, os orgâno-fosforados são os mais tóxicos (em termo de toxidade aguda), mas se degrada rapidamente no ambiente e não se acumula nos tecidos gordurosos. Atua inibindo a ação da enzima colinesterase na transmissão do impulso nervoso;

\section{- Os carbamatos}

Os carbamatos são os agrotóxicos compostos por ésteres de ácido metilcarbônico ou dimetil-carbônico. Em relação aos agrotóxicos organoclorados e organofosforados, os carbamatos são considerados de toxicidade média, sendo degradado rapidamente e não se acumulando nos tecidos gordurosos. Os carbamatos também atuam inibindo a ação da colinesterase na transmissão dos impulsos nervosos cerebrais;

- Os fungicidas, (dicloro-propano-dicloropropenos), molusquicidas (4tritilmorfolina) e herbicidas (ácidos alifáticos clorados e os fenoxiácidos), que são combinados com os inseticidas.

Muitos destes produtos foram proibidos em diversos países, também em virtude de seu efeito altamente cancerígeno. Os agrotóxicos organoclorados ainda são incluídos na legislação para análise obrigatória em águas de abastecimento, em virtude de sua difícil degradação natural e são encontrados ainda resíduos no solo e na água. Pois os organoclorados acumulam-se na cadeia alimentar e são muito persistentes no ambiente ${ }^{(16)}$.

Em 23 de maio de 2001 em Estocolmo, foi assinada por 90 países, incluindo o Brasil, a Convenção sobre Poluentes Orgânicos Persistentes 
(POPs), que é um tratado internacional para proibir a produção e uso de 12 substâncias orgânicas tóxicas, conhecidas como "a dúzia suja", que são o aldrin, clordano, mirex, dieldrin, DDT, dioxinas, furanos, PCBs, endrin, heptacloro, HCBs e toxafenos. Estas substâncias são acusadas de causar câncer e má formação em humanos e animais de todo o mundo. O Brasil não produz a maioria destas substâncias, mas usa três delas, que são o HCB, DDT, e heptacloro ${ }^{(61)}$.

\subsubsection{Consumo de agrotóxicos no Brasil}

O clima tropical do Brasil beneficia o desenvolvimento de pragas agrícolas, motivando a utilização de defensores agrícolas. Na safra de 1970/1971 foram utilizadas 27 mil toneladas de agrotóxicos, passando de 81 mil toneladas na safra de 1980, colocando o Brasil entre os maiores consumidores de agrotóxicos no mundo. Dados estatísticos da Associação Nacional de Defensivos Agrícolas (ANDEF) mostram que os o uso de agrotóxicos dobrou de volume na década de 90 , sendo que os herbicidas representam cerca de $90 \%$ desse aumento ${ }^{(19,72)}$.

A utilização de defensivos agrícolas vem crescendo a cada ano. A demanda das principais culturas chegou a 160 mil toneladas em 2003, o que coloca o Brasil em oitavo lugar no mundo, com um crescimento médio de $11,4 \%$ ao ano, em comparação com aumento de $1 \%$ a $2 \%$ ao ano nos países desenvolvidos. Em 2007, o Brasil ficou em segundo lugar, atrás apenas dos Estados Unidos ${ }^{(71)}$.

As culturas que mais consomem defensivos agrícolas pela ordem são a de soja $(38,06 \%)$, de cana-de-açúcar $(11,51 \%)$, de algodão $(9,09 \%)$, de milho $(7,82 \%)$, de citros $(5,94 \%)$, de trigo $(3,48 \%)$, de batata $(2,49 \%)$, de arroz $(2,45 \%)$ e de café $(2,42 \%)$. As demais culturas representam $13,27 \%$ do consumo nacional. A categoria de agrotóxico mais utilizado no Brasil são os herbicidas seguidos pelos inseticidas e fungicidas. Na Figura 1 é apresentada a evolução do consumo de agrotóxicos de 2007 para $2008^{(23,72)}$. 


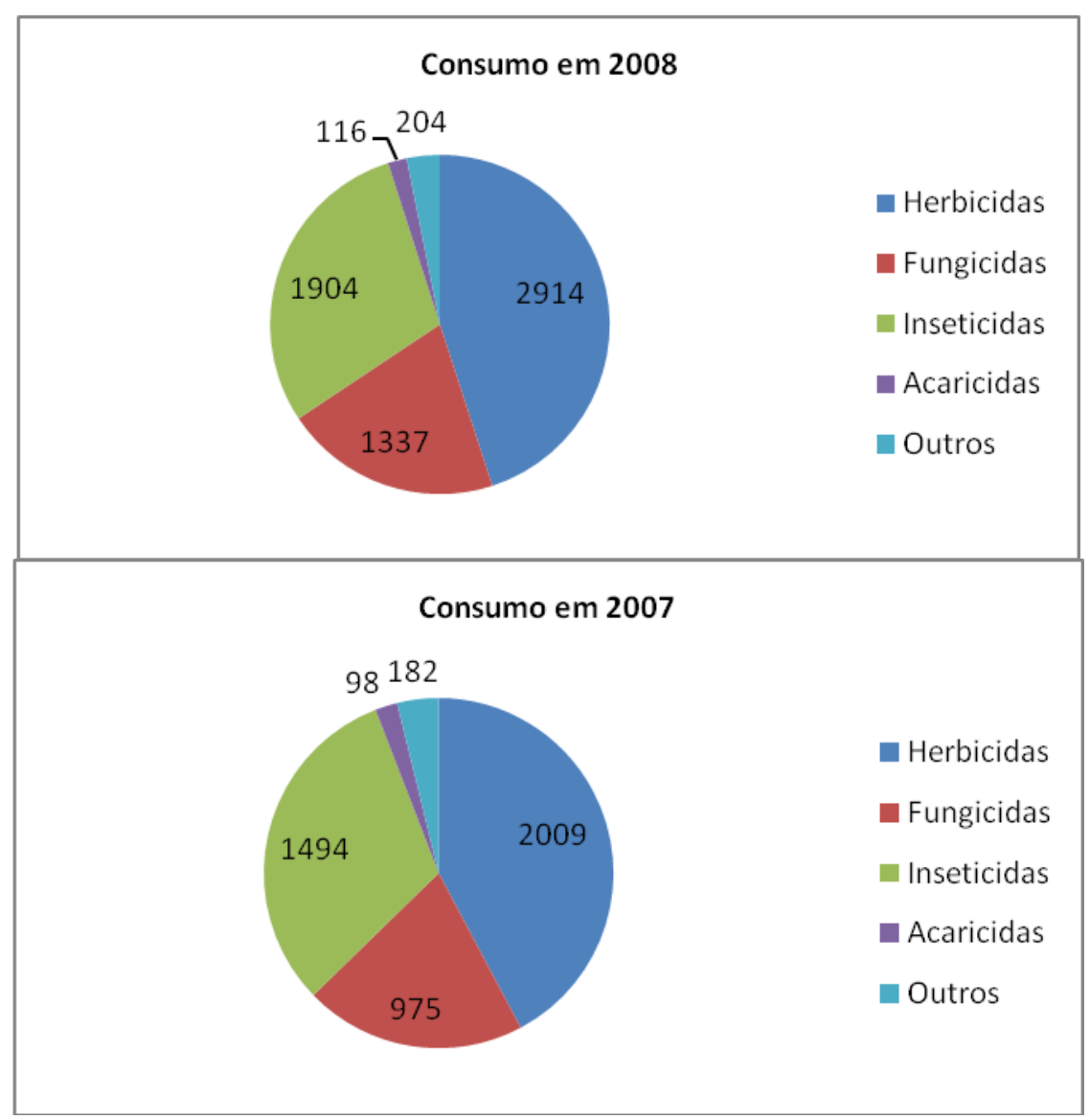

Figura 1. Estimativa do mercado de defensivos agrícola no período de Janeiro à Agosto de 2007 e 2008 em Milhões de reais ${ }^{(72)}$.

\subsubsection{O Problema das Embalagens de Agrotóxicos}

Outro problema relacionado à utilização de defensivos agrícolas é a descontaminação e o destino final dado às suas embalagens. No início da década de 90, a Associação Nacional de Defesa Vegetal (ANDEF) iniciou um programa de busca de solução mais efetiva para o descarte das embalagens de agrotóxicos ${ }^{(12)}$.

Em 1992, uma parceria foi firmada entre a ANDEF, a Secretaria da Agricultura, a Associação dos Engenheiros Agrônomos do Estado de São Paulo (AEASP) e a Cooperativa dos Plantadores de Cana da Zona de Guariba (Coplana). Esta parceria tinha o objetivo de estudar o fluxo das embalagens vazias de agrotóxicos e implantar a primeira unidade piloto de recebimento destas embalagens, que entrou em atividade em $1994{ }^{(12)}$. 
No ano de 1997, com mais parceiros, foi prevista a criação de uma entidade. Neste mesmo ano, a Associação Brasileira de Normas Técnicas (ABNT) publica a NBR 13.968/1997, norma que regulamenta a lavagem de embalagens vazias de defensivos agrícolas. Com esse procedimento, as embalagens passam a ser consideradas dejeto comum ao invés de resíduo perigoso, possibilitando sua reciclagem.

Em 2001 concluiu-se que seria necessária a criação de uma entidade capaz de coordenar a destinação final das embalagens vazias. Assim, em 14 de dezembro de 2001 foi criado o Instituto Nacional de Processamento de Embalagens Vazias, INPEV, que iniciou suas atividades em janeiro de 2002, com o objetivo de implantar um sistema ágil e eficiente de processamento de embalagens vazias de defensivos agrícolas. A meta do INPEV e de seus parceiros que são os órgãos públicos, agricultores, revendedores, entidades e empresas privadas, cooperativas, ONGs, associações de classe, patronais e de trabalhadores, é oferecer apoio logístico a essa ação de âmbito nacional, fazendo com que todos os elos envolvidos na cadeia do agronegócio contribuam de maneira efetiva, para a sustentabilidade ambiental ${ }^{(48)}$.

Atualmente, são 376 unidades de recebimento, que envolvem mais de 2000 distribuidores e cooperativas que comercializam produtos fitossanitários no país ${ }^{(48)}$.

As embalagens de agrotóxicos podem ser recicladas quando submetidas ao processo de tríplice lavagem ou ao processo de lavagem sob pressão. Quando não é submetida ao processo de lavagem, a embalagem é incinerada.

A reciclagem de embalagens de agrotóxicos apresenta um aspecto positivo e foi implantada com o objetivo de eliminar o impacto ambiental causado por resíduos sólidos. As embalagens, após uso do produto e a lavagem, são devolvidas aos fornecedores e estes as encaminham para locais de coleta.

Os agricultores devem efetuar a devolução das embalagens vazias aos estabelecimentos comerciais em que foi efetuada a compra e antes de serem devolvidas, devem ser submetidas ao processo de tríplice lavagem. Os comerciantes devem dispor de instalações adequadas para recebimento e 
armazenamento das embalagens vazias. As empresas que fabricam e comercializam agrotóxicos são responsáveis pelo recolhimento, transporte e destinação final das embalagens devolvidas pelo usuário.

A tríplice lavagem é feita no local de uso e efetuada nas embalagens rígidas de plástico, metal ou vidro que contenham formulações líquidas de agrotóxico para serem diluídos em água, conforme especificação da norma técnica NBR 13.968/1997. Os objetivos da tríplice lavagem são: economia com o aproveitamento total do produto sem deixar restos na embalagem, segurança e proteção ambiental evitando riscos de contaminação do solo e mananciais. Cerca de $90 \%$ das embalagens recolhidas pelo INPEV podem ser recicladas, desde que estejam corretamente lavadas, entretanto o volume de embalagens devolvidas contaminadas é grande sendo necessário encaminhá-las para incineração ${ }^{(48)}$.

\subsection{Solo e suas características}

O solo é um espaço de vital importância para o desenvolvimento das nossas plantas. É onde nascem, crescem e se multiplica a maioria das espécies vegetais existentes na natureza, talvez, a matéria-prima mais importante, a seguir à água que desempenham função primordial no atendimento às necessidades alimentares à humanidade, a qualidade e o tipo de solo, determina o padrão de vida dos que nele vivem, pois serve de alicerce para moradia e espécie de planta e agricultura que desenvolverá ${ }^{(17,53,58)}$.

O solo é constituído essencialmente por matéria mineral, matéria orgânica, água e ar e pode ser considerado como um sistema trifásico, pois se divide em três frações: fração sólida (matéria mineral associada à matéria orgânica), fração líquida (água) e fração gasosa (ar). As proporções de matéria orgânica e matéria mineral podem variar consoante a natureza dos solos. No entanto, quer estes tenham muita ou pouca matéria mineral ou matéria orgânica os solos contêm proporções variáveis de água com substâncias dissolvidas (solução do solo) e ar (atmosfera do solo) ${ }^{(17,20)}$. 
A matéria orgânica é formada por distintos tipos de organismos como raízes vegetais, insetos, bactérias e fungos, juntamente com restos animais e vegetais em decomposição, vulgarmente denominados por húmus. A matéria inorgânica provém de rocha erudita, sendo, portanto, o resultado da lenta degradação da rocha mãe, produto de processos físicos e químicos, que resultam em diversas formas e tamanhos ${ }^{(21,53)}$.

A matéria mineral do solo pode incluir, em proporções variáveis, fragmentos de rocha, minerais primários, como resultado da fragmentação da rocha-mãe e minerais de origem secundária, estes resultantes da alteração dos primários que são os minerais de argila, óxidos e hidróxidos de alumínio e ferro e por vezes, carbonatos de cálcio, magnésio, entre outros. O solo apresenta-se na forma de fragmentos ou partículas de formas e dimensões muito variáveis, desde pedras de cascalho até materiais tão finos que apresentam propriedades coloidais. As proporções destas partículas no solo permitem definir a textura destes compostos, tais como a argila, menor que $4 \mu \mathrm{m}$; o silte, maior que $4 \mu \mathrm{m}$ e menor que $64 \mu \mathrm{m}$ e a areia, maior que $64 \mu \mathrm{m}$ e menor que $2 \mathrm{~mm}{ }^{(53)}$.

A matéria orgânica do solo é constituída por restos de plantas e outros organismos, em estado mais ou menos avançado de decomposição (devida essencialmente à atividade de microrganismos), incluindo substâncias no estado coloidal. Esta se acumula principalmente à superfície dos solos, facilitando assim a penetração das raízes, a retenção da água e o arar dos solos. A matéria orgânica que sofreu intensa decomposição através de processos químico-biológicos e atingiu certo grau de estabilidade, é designada por húmus, de cor escura e heterogênea e com propriedades coloidais ${ }^{(6)}$.

As condições climáticas são a principal influência das características de cada solo. No entanto, também existem outros fatores que influenciam fortemente o tipo de solo, como a rocha-mãe, o declive do terreno e os organismos do solo. As diferentes combinações entre estes fatores dão origem a diferentes tipos de solos com características e propriedades extremamente variadas ${ }^{(6,8,17)}$ : 


\section{- Solo de textura arenosa}

O solo arenoso possui teor de areia superior a 70\%, têm boa aeração e pouca umidade o que leva a plantas e microorganismos viverem com mais dificuldade,. Também possui argila e outros compostos em menor percentagem, mas como tem boa aeração não retém água. Esse solo é permeável os grãos de areia são maiores e tem mais espaço entre si, facilitando a passagem da água; 63

\section{- Solo de textura argilosa}

Os solos argilosos não são tão areados, mas armazenam mais água. São menos permeáveis a água que fica armazenada por passar mais lentamente. Alguns solos brasileiros, mesmo tendo muita argila, apresentam grande permeabilidade porque possui elevada quantidade de óxidos de alumínio (gibbsita) e de ferro (goethita e hematita), que formam pequenos grãos semelhantes ao pó-de-café, isso lhe dá um caráter similar ao arenoso. ${ }^{63}$

\section{- Solos de textura média}

Os solos de textura média são solos que apresentam certo equilíbrio entre os teores de areia, silte e argila. Normalmente, apresentam boa drenagem, boa capacidade de retenção de água e índice médio de erodibilidade. Portanto, não necessitam de cuidados especiais, adequando-se a todos os métodos de irrigação; ${ }^{63}$

\section{- Solos de textura siltosa}

Os solos siltosos possuem grande quantidade de silte, geralmente são muito erodíveis. O silte não se agrega como a argila e ao mesmo tempo suas partículas são muito pequenas e leves; ${ }^{63}$

\section{- Solo humífero}

O solo humífero apresenta uma quantidade maior de húmus em relação aos outros. É um solo geralmente fértil, ou seja, um solo onde os vegetais encontram melhores condições para se desenvolverem. Possuem cerca de $10 \%$ de húmus em relação ao total de partículas sólidas. A presença de húmus 
dá uma coloração, em geral, escura, contribui para sua capacidade de reter água e sais minerais e aumenta sua porosidade e aeração. Os grãos são de tamanhos variados e diversificados e a passagem da água ocorre de acordo com o tipo de grão; ${ }^{63}$

\section{- Solo calcário}

A quantidade de calcário nesse tipo de solo é maior que nos outros. Desse tipo de solo é retirado um pó branco ou amarelado, que pode ser utilizado na fertilização dos solos destinados à agricultura e à pecuária. Esse solo também fornece a matéria-prima para a fabricação de cal e do cimento. ${ }^{20}$

\subsubsection{Contaminação de Solos por Agrotóxicos}

Os problemas relacionados às contaminações dos solos têm despertado a atenção de muitas organizações mundiais, dentre as quais podemos citar a Organização das Nações Unidas para a Alimentação e a Agricultura (FAO), que possui um programa de prevenção e eliminação de inseticidas obsoletos e indesejados, destinado a ajudar os países em desenvolvimento, a identificar e a eliminar as reservas obsoletas de inseticidas. Além disso, existem dois instrumentos internacionais juridicamente vinculativos que abordam sobre a produção, a utilização e a liberação de poluentes orgânicos persistentes e a gestão segura dos resíduos que contenham estas substâncias, com o objetivo de proteger a saúde humana e o ambiente dos seus efeitos. Uma vez que os países em desenvolvimento e os países com economias em transição nem sempre dispõem de instalações adequadas para a destruição ou reprocessamento seguros destas reservas e de solos contaminados, existem acordos e programas internacionais que prevêem a transferência deste solo para uma instalação de tratamento, para efeitos de transformação ou destruição ${ }^{(15,29,34)}$.

O acúmulo de resíduos sólidos no ambiente de áreas rurais com o descarte de embalagens de agrotóxicos contaminadas causa poluição e contaminação em rios, águas subterrâneas e no solo. A contaminação de solos é um problema que atinge grande parte do mundo. Estudos feitos na Grã- 
Bretanha mostram que mais de $90 \%$ da carga de contaminantes orgânicos que entram no ambiente acabam atingindo o solo. O problema torna-se ainda mais grave quando envolve substâncias persistentes, como os organoclorados, que podem permanecer no solo por vários anos ${ }^{(16,23)}$.

O comportamento dos agrotóxicos no solo depende de algumas características do próprio agrotóxico e de sua interação nos diferentes tipos de solos, como exemplo pode-se $\operatorname{citar}^{(6,16,63,69)}$ :

\section{- A volatilidade}

A volatilidade dos agrotóxicos no solo é muito variável, assim como sua tendência à perda para a atmosfera, em alguns casos o agrotóxico é selecionado por sua pressão de vapor muito elevada que permite sua penetração nos poros do solo, para atingir os organismos; ${ }^{16,23}$

\section{- A adsorção}

A tendência a serem adsorvidos pelos solos é, em grande parte, determinada pelas características do próprio agrotóxico assim como a do solo que são adicionados. A presença de certos grupos funcionais com $\mathrm{OH}, \mathrm{NHR}, \mathrm{CONH}_{2}$, COOR e NR, na estrutura molecular dos produtos químicos, estimula a adsorção.

\section{- A lixiviação}

A tendência dos agrotóxicos à lixiviação dos solos é diretamente relacionada com seu potencial de adsorção, pois moléculas que têm forte interação dificilmente se submetem ao sentido descendente do perfil. A movimentação da água poderá favorecer a lixiviação, que se realiza com maior rapidez em solo arenoso com quantidade reduzida de argila e matéria orgânica;

\section{- O metabolismo microbiano}

A degradação bioquímica exercida pelos organismos é talvez o método singular mais importante de remoção dos agrotóxicos do solo, pois a presença 
de certos grupos polarizados nas moléculas dos agrotóxicos proporciona pontos de ataque ao organismo, tais como $\mathrm{OH}, \mathrm{NHR}, \mathrm{CONH}_{2}, \mathrm{COOR}$ e NR;

\section{- A persistência nos solos}

A persistência dos agrotóxicos nos solos é o somatório de todas as reações, movimentos e degradações que exercem influência sobre os mesmos, em geral os organoclorados são os que apresentam maior tempo de persistência em comparação aos outros agrotóxicos organo-sintéticos. ${ }^{(3,19,26)}$

\subsubsection{Fatores que influenciam a absorção de agrotóxicos pelo solo}

Os agrotóxicos no solo assumem três formas, que são a solúvel ou disponível, a absorvida ou em equilíbrio dinâmico e a ligada fortemente à estrutura do solo. A influência da matéria orgânica na persistência do agrotóxico no solo é bem conhecida. Alguns agrotóxicos degradam muito rapidamente em solos com quantidade elevada de matéria orgânica e outros são degradados lentamente ${ }^{(24,40)}$. A sorção é o processo primário que rege o transporte e comportamento de agrotóxicos iônicos e não iônicos no solo. Os agrotóxicos não extraíveis ou ligados fortemente no solo, não são lixiviados e possuem pouca biodisponibilidade para decomposição por microorganismos ${ }^{(1,3,19,26,51)}$.

Além dos grupos funcionais dos produtos químicos, o $\mathrm{pH}$ do solo e a constante de ionização ácido/base destas substâncias químicas em estudo tem forte influência no mecanismo de adsorção do solo com os agrotóxicos. As constantes de ionização ácido/base representam a maior ou menor tendência (força) do agrotóxico em se ionizar, pois formas ionizadas dos agrotóxicos se comportam diferentemente das formas não ionizadas (neutras). Tais comportamentos podem ser verificado em função das seguintes equações $1 \mathrm{e}$ 2:

$$
\begin{aligned}
& \mathrm{Pk}_{\mathrm{b}}+(\mathrm{pH}-14)=\log [\mathrm{B}] \cdot\left[\mathrm{BH}^{+}\right]^{-1} \\
& \mathrm{Pk}_{\mathrm{a}}-\mathrm{pH}=\log \cdot\left[\mathrm{BH}^{+}\right][\mathrm{B}]^{-1}
\end{aligned}
$$


Quanto maior forem os valores de $\mathrm{pk}_{\mathrm{a}}$ e $\mathrm{pk}_{\mathrm{b}}$ dos agrotóxicos, terá menor tendência a reagir, portanto será menos adsorvido pelo solo. Com base nestas equações podemos afirmar que ${ }^{(36)}$ :

- Se o pH do solo for igual ao $\mathrm{pk}_{\mathrm{b}}$ do agrotóxico, há uma tendência do agrotóxico se apresentar com uma concentração maior na forma catiônica em $\mathrm{pH}=\mathrm{pk}_{\mathrm{b}} \leq 6$ ou na forma molecular em $\mathrm{pH}=\mathrm{pk}_{\mathrm{b}} \geq 8$;

- Se o pH do solo for menor que o $\mathrm{pk}_{b}$ do agrotóxico, há uma tendência do agrotóxico se apresentar com uma concentração maior na forma catiônica em $\mathrm{pH} \leq 5$ ou na forma molecular em $\mathrm{pH} \geq 7$;

- Se o pH do solo for maior que o pk $\mathrm{p}_{\mathrm{b}}$ do agrotóxico, há uma tendência do agrotóxico se apresentar com uma concentração maior na forma catiônica em $\mathrm{pH} \leq 7$. Isso ocorre principalmente com uma ou mais unidade de $\mathrm{pH}$ acima do valor do $\mathrm{pk}_{\mathrm{b}}$ do agrotóxico básico. Nestas condições o agrotóxico tem grandes possibilidades de ficar sorvido aos componentes do solo e não ser transportado para outras partes do ambiente em valores de $\mathrm{pH} \geq 8$ pode haver um equilíbrio entre as concentrações das formas catiônicas e moleculares e com tendências a predominarem as concentrações das formas moleculares à medida que 0 $\mathrm{pH}$ aumenta, observando sempre valores de $\mathrm{pk}_{\mathrm{b}}$ menores que $\mathrm{pH}$ da solução do solo;

- Se o pH do solo for igual ao $\mathrm{pk}_{\mathrm{a}}$ do agrotóxico, há uma tendência do agrotóxico se apresentar com uma concentração igual na forma catiônica e molecular;

- Se o pH do solo for menor ao $\mathrm{pk}_{\mathrm{a}}$ do agrotóxico, há uma tendência do agrotóxico se apresentar com uma concentração menor na forma catiônica do que na forma molecular;

- Se o pH do solo for maior ao $\mathrm{pk}_{\mathrm{a}}$ do agrotóxico, há uma tendência do agrotóxico se apresentar com uma concentração maior na forma catiônica do que na forma molecular. 


\section{Adsorção em função da matéria orgânica do solo}

Uma forma de avaliar-se a sorção e a mobilidade de substâncias orgânicas no solo é através dos valores de Kd (coeficiente de distribuição), que também pode ser denominado de coeficiente de partição; Koc (coeficiente de partição correlacionado com substâncias orgânicas); e Kow (fator de hidrofobicidade) ${ }^{(2)}$.

$\mathrm{Kd}=\mathrm{S} \cdot \mathrm{C}^{-1}\left(\mathrm{LKg}^{-1}\right)$

$\mathrm{Koc}=\mathrm{Kd}$. Foc ${ }^{-1}$

onde:

$\mathrm{S}=$ massa do contaminante na fase sólida do solo $\left(\mathrm{mg} \mathrm{kg}^{-1}\right)$;

$\mathrm{C}=$ massa do contaminante na fase líquida $\left(\mathrm{mg} \mathrm{L}^{-1}\right)$.

O parâmetro $\mathrm{Kd}\left(\mathrm{L} \mathrm{kg}^{-1}\right)$ é uma importante ferramenta na estimativa do potencial de sorção do contaminante dissolvido em contato com o solo. Quanto maior o Kd, maior a tendência do contaminante ficar adsorvido ao solo ou sedimento.

Devido à importância do carbono orgânico presente no solo no processo de sorção e distribuição de compostos orgânicos, o coeficiente de distribuição (Kd) é geralmente expresso por Koc; onde Koc é o coeficiente de partição do contaminante na fração orgânica do solo.

$\mathrm{Koc}=\mathrm{Kd} . \mathrm{Foc}^{-1} \quad$ (Eq. 5)

onde:

Koc $=$ coeficiente de partição normalizado pelo carbono orgânico $\left(\mathrm{L} \mathrm{kg}{ }^{-1}\right.$ substância orgânica);

foc = fração de carbono orgânico ( $k$ g substância orgânica/kg solo seco).

Koc é, portanto, o coeficiente de partição do contaminante entre soloágua corrigido pela matéria orgânica do solo. A força de sorção entre a substância orgânica e o solo é medida pelo coeficiente de partição Koc, que 
depende das propriedades físico-químicas deste contaminante e da porcentagem de carbono orgânico do solo. ${ }^{2}$

Os valores de Koc são normalmente determinados com base nos valores de Kd e corrigidos pela fração orgânica do solo. No manual de valores de Koc para solo são apresentadas amplas faixas de valores de Koc para um grande número de compostos orgânicos, que foram obtidas, em sua maioria, por isotermas de sorção. A relação entre Kow e Koc é freqüentemente utilizada para estabelecerem-se os valores de Koc. Esta forma simplificada aparentemente representa bem a sorção de contaminantes orgânicos ao solo.

O coeficiente de partição octanol-água, Kow, é outro importante coeficiente para a mobilidade de alguns materiais orgânicos. Kow é definido como a relação da concentração em equilíbrio de um contaminante orgânico na fase octanol em relação à concentração do contaminante na fase aquosa.

O valor de Kow pode ser usado para estimar o comportamento de compostos orgânicos hidrofóbicos que não interagem eletricamente com a superfície do solo. O Kow é um coeficiente muito útil para previsão de outros parâmetros como Koc, quando este não se encontra disponível na literatura (Eq.6).

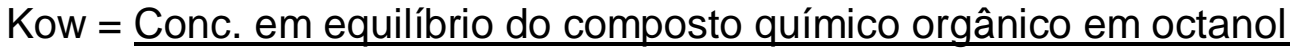

Conc. do composto químico em água

Kow é uma medida que define a hidrofobicidade de um composto orgânico e é um parâmetro comumente utilizado na área ambiental. Koc está fortemente correlacionado com Kow, em uma relação linear expressa pela equação abaixo:

$\log \mathrm{Koc}=\mathrm{a} \log \mathrm{Kow}+\mathrm{b}$

onde a e b são coeficientes relacionados com os compostos e tipo de matéria orgânica sobre o solo (2) 


\subsubsection{Técnicas de Remediação de Solos}

A comunidade cientifica têm se mobilizado, para obter métodos e processos de remediação de solo contaminados por agrotóxicos, dentre os quais, pode-se destacar a lavagem de solo, a eletro-migração, a vitrificação, a extração com fluido super crítico e o processo de oxidação avançada de compostos orgânicos tóxicos, POAs, que são baseados em reações oxidativas iniciadas por radical hidroxila $(\cdot \mathrm{OH})$.

Em geral, as tecnologias para tratamento de solos contaminados com compostos orgânicos recaem em três categorias: imobilização do

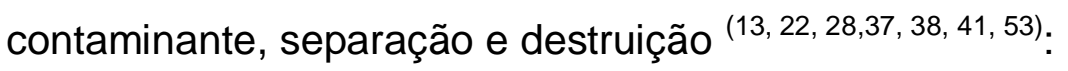

\section{- Imobilização}

As tecnologias de imobilização consistem na criação de barreiras físicas para evitar a migração dos contaminantes e são bastante utilizadas devido à sua grande praticidade e baixo custo. Porém, este método simplesmente isola o contaminante evitando que o mesmo possa se espalhar e causar maiores danos ao ambiente e à saúde humana, atingindo cursos d'água superficiais ou subterrâneos. Além disso, geralmente existe um limite de espaço físico destinado ao armazenamento dos resíduos e o aumento descontrolado na produção destes pode se tomar um grande transtorno. Vide, por exemplo, o problema dos lixões e aterros sanitários na cidade de São Paulo;

\section{- Separação}

A separação consiste em se extrair o contaminante para uma fase de gerenciamento mais fácil (líquida ou gasosa) ou para uma fase mais concentrada, reduzindo o volume do material a ser remediado ou disposto. Dentro da categoria de separação pode-se citar a lavagem do solo, a extração com solvente, a desorção térmica e a extração com fluido supercrítico ${ }^{(16)}$. Nos processos de lavagem do solo e extração com solvente, a remoção da porção afetada e sua lavagem são feitas com solventes adequados para cada tipo de contaminante, como por exemplo, com detergentes para óleos e derivados de petróleo ou quelantes para metais pesados. A principal desvantagem desse tipo 
de processo é que, embora haja equipamentos adequados para tal finalidade, eles são muito grandes, exigem grande número de pessoal especializado e, principalmente, geram grande quantidades de resíduos líquidos contaminados. $\mathrm{Na}$ desorção térmica o processo mais utilizado é a injeção de vapor d'água no solo através de tubulações. Neste caso, o vapor a alta temperatura arrasta os contaminastes, extraindo-os do solo e sendo em seguida sugados por pontos de vácuo e enviados para filtros ou condensadores para receber, posteriormente, o tratamento adequado. $\mathrm{Na}$ extração com fluído supercrítico é passado, através do solo contaminado, um gás à alta pressão (400 bar) e temperatura $\left(150^{\circ} \mathrm{C}\right)$ que arrasta os contaminantes, o qual é então recolhido da mesma forma que o vapor d'água. Geralmente o fluído escolhido é o $\mathrm{CO}_{2}$ pela sua baixa toxicidade $(45,60,64,76,77)$.

\section{- Decomposição}

As técnicas de decomposição são aquelas que visam à total mineralização dos contaminantes, convertendo-os em água, gás carbônico e íons inorgânicos. Porém, nem sempre este resultado é alcançado e assim compostos intermediários podem ser formados com toxicidade maior que a do composto original, daí a necessidade da identificação dos metabólitos ou produtos de degradação. Há vários estudos sobre o uso da biorremediação "in situ", utilizando um consórcio de microorganismos que parece causar menos impacto ao ambiente. No entanto, considerando que alguns resíduos podem ser tóxicos aos microorganismos normalmente utilizados nesse processo de remediação, pode ser necessário período de tempo longo para se alcançar a redução da contaminação ${ }^{(64,71,75)}$.

No caso da incineração, por exemplo, observou-se a formação de dioxinas e furanos, suspeitos de serem altamente tóxicos e cancerígenos, quando da combustão em temperaturas moderadas. Para evitar isso, alguns requisitos devem ser cumpridos para o uso de incineradores tais como a instalação de filtros e melhor controle da temperatura, o que encarece o sistema tornando-o menos vantajoso.

Os Processos de Oxidação Avançada, POA, são baseados em reações oxidativas iniciadas por radical hidroxila $(\cdot \mathrm{OH})$. $\mathrm{O}$ elevado potencial de 
redução deste radical (2,8 V contra o eletrodo normal de hidrogênio) possibilita a oxidação, não seletiva, de uma variedade de contaminantes orgânicos. Existem vários processos para gerar estes radicais em água, como o ozônio, o peróxido de hidrogênio, a radiação ultravioleta (UV) e a radiação ionizante ${ }^{(1,7,13,}$ $30,32,46,56,75,78)$

Dentre as várias alternativas existentes para a produção de radical hidroxila pode ser dado destaque à fotocatálise heterogênea, principalmente na presença de $\mathrm{TiO}_{2}$, fotólise assistida por peróxido de hidrogênio, sistemas Fenton e Radiação lonizante, processos estes bastante explorados para a degradação de inúmeros poluentes orgânicos de relevância, principalmente presente nos agrotóxico e derivados de petróleo.

Vale salientar que a radiação UV mostra-se muito eficiente para quebra de ligações covalentes (ligações entre não-metais, predominante nos agrotóxicos e derivados de petróleo), principalmente com auxilio do peróxido de hidrogênio, e ainda mais eficiente com a utilização de $\mathrm{Fe}^{+3}$ como catalisador ${ }^{\text {(37) }}$. Reação fenton, caracteriza-se pela presença de peróxido, $\mathrm{Fe}^{+3}$, conforme descrito abaixo.

$$
\mathrm{Fe}^{+3}+\mathrm{H}_{2} \mathrm{O} \longrightarrow \mathrm{Fe}^{+2}+\mathrm{H}^{+}+\mathrm{HO}^{\cdot}
$$

Reação foto-fenton, caracteriza-se pela presença de peróxido, $\mathrm{Fe}^{+3}$ e radiação UV, conforme descrito abaixo.

$$
\mathrm{Fe}^{+3}+\mathrm{H}_{2} \mathrm{O}+\mathrm{hv} \longrightarrow \mathrm{Fe}^{+2}+\mathrm{H}^{+}+\mathrm{HO}^{-}
$$

\subsection{Aplicação da Radiação lonizante na Degradação de Agrotóxicos}

A tecnologia nuclear tem sido utilizada no estudo do comportamento dos agrotóxicos através do rastreamento de agrotóxicos radiomarcados com 
Carbono-14 em todos os segmentos do ambiente, como na translocação e metabolismo em solo, plantas e animais fornecendo informações importantes na cadeia alimentar ${ }^{(25,47,58)}$.

A radiólise dos agrotóxicos pode ocorrer pela interação direta da radiação ionizante na molécula ou pela interação indireta com os produtos da radiólise da água. A ação direta da radiação é insignificante mesmo em casos de concentrações altas do agrotóxico. $\mathrm{Na}$ radiólise indireta a molécula do composto reage com os radicais $\mathrm{e}_{\text {-aq. }}, \mathrm{H}^{+}, \mathrm{OH}^{-}$e produto molecular $\mathrm{H}_{2} \mathrm{O}_{2}$ que são formados nas seguintes proporção ${ }^{(24,33,38,39,40,54,55)}$.

$$
\mathrm{H}_{2} \mathrm{O} \longrightarrow(2.6) \mathrm{e}_{\text {-aq. }}+(0.6) \mathrm{H}^{+}+(2.7) \mathrm{OH}^{-}+(0.7) \mathrm{H}_{2} \mathrm{O}_{2}+(2.6) \mathrm{H}_{3} \mathrm{O}^{+}+(0.45) \mathrm{H}_{2}
$$

Dos produtos formados, as espécies mais reativas são a radical hidroxila oxidante $(\mathrm{OH}-)$, o elétron aquoso redutor (e-aq.) e o átomo de hidrogênio $(\mathrm{H}+)$. Assim, os processos químicos básicos ocorrerão reação com estas três espécies.

$\mathrm{Na}$ irradiação com feixe de elétrons os produtos da radiólise da água tendem a reagir com os grupos funcionais presentes nas moléculas orgânicas preferencialmente à molécula como um todo. Alguns grupos funcionais como os tióis e aqueles contendo múltiplas insaturações, são atacados preferencialmente se estiverem presentes ${ }^{(42,62)}$.

Javaroni e colaboradores ${ }^{(50)}$ determinaram a taxa de degradação do lindano, isomero tóxico do benzeno hexaclorado, $\mathrm{BHC}$, persistente no ambiente e inerte aos ataques de ácidos e bases, quando submetido a uma dose de radiação gama. Segundo os dados obtidos por cromatografia, o lindano, não obstante pertencer a classe dos inseticidas mais persistentes, não resiste aos efeitos da radiação gama. Concluem os autores que a radiação ionizante poderá ser utilizada como um meio de descontaminação ambiental.

Luchini e colaboradores ${ }^{(59)}$ irradiaram o paration diluído em metanol. Com uma dose de $30 \mathrm{kGy} 99 \%$ do inseticida foi degradado e os produtos foram idênticos aos produtos de degradação em meio aquoso identificados por Landgraf e colaboradores ${ }^{(58)}$. 
Vel Leitner e colaboradores ${ }^{(74)}$ estudaram a degradação da atrazina em água contendo substâncias húmicas por meio de radiação gama borbulhando nitrogênio, oxigênio, $\mathrm{N}_{2} \mathrm{O}$ e uma mistura gasosa de $\mathrm{N}_{2} \mathrm{O} / \mathrm{O}_{2}$. Existe uma diferença predominante na formação de radicais quando se borbulha tipos diferentes de gases. Borbulhando nitrogênio há predominância na formação de elétron aquoso, borbulhando a mistura gasosa de $\mathrm{N}_{2} \mathrm{O} / \mathrm{O}_{2}$ há predominância de formação de radical hidroxila. A degradação da atrazina é realizada pela ação do radical hidroxila e pelo elétron solvatado. A degradação foi mais eficiente borbulhando nitrogênio. Para o tratamento de águas naturais, borbulhar nitrogênio não é a melhor solução. Águas naturais contêm nitrato que capturam elétrons diminuindo a eficiência do sistema de irradiação.

Angelini e colaboradores ${ }^{(7)}$ estudaram a degradação radiolítica da atrazina com uma concentração próxima a encontrada no ambiente. Em solução a degradação é causada pela ruptura da ligação carbono-cloro e o halogênio é substituído por um radical hidroxila estabilizando a estrutura aromática. A atrazina foi completamente degradada com uma dose de 0,1 kGy, porém, alguns produtos da radiólise resistiram a dose de 50 kGy.

Abdel e colaboradores (1) investigaram a degradação de dois inseticidas, pertencentes a dois grupos químicos, em solução aquosa por radiação gama e acelerador de elétrons. O lannate pertence ao grupo tiuréia e o fenvalerato ao grupo fenilacetato. A degradação do lannate foi maior do que a degradação do fenvalerato nos dois sistemas de irradiação. Essa diferença de comportamento é explicada pela diferença das estruturas químicas dos inseticidas. O lannate é um composto alifático e o fenvalerato possui três anéis aromáticos. Compostos alifáticos são mais sensíveis a radiação e o benzeno mais resistente, porém, a taxa de degradação no acelerador foi maior do que no irradiador gama para os dois compostos.

O ácido 2,4-D, ácido 2,4-diclorofenol acético é um herbicida utilizado no controle de uma grande variedade de ervas daninhas. Tem alta solubilidade em água e após aplicação atinge as águas dos lençóis subterrâneos pela ação das águas da chuva e irrigação. Zona e Solar ${ }^{(79)}$ estudaram a degradação do ácido 2,4-D e a influência da concentração de oxigênio na mineralização dos produtos intermediários com radiação gama, com uma dose de 4 kGy ocorreu 
a degradação total de $100 \mathrm{mg} / \mathrm{L}$ do herbicida. Os produtos intermediários encontrados foram os ácidos 2-cloro-4-hidroxi e 4-cloro-2-hidroxi fenoxiacético. Injetando-se oxigênio na solução durante irradiação os produtos intermediários são degradados, com a mesma dose necessária para a degradação do ácido 2,4-D, formando ácido acético como principal produto.

Curry and Mincher ${ }^{(28)}$ compararam a radiólise de PCB após sua remoção do solo, usando solventes polares e não polares e a eficiência foi muito menor do que quando aplicada em compostos solúveis em água diretamente no solo.

\subsubsection{Fontes de Radiação lonizante}

No processo avançado de oxidação utilizando radiação ionizante empregam-se, basicamente, dois tipos de irradiadores: aqueles que utilizam radioisótopos artificiais emissores gama, como cobalto-60 e césio-137 e os aceleradores de elétrons ${ }^{(31,33,66)}$.

As fontes gama requerem blindagens especiais de concreto com paredes espessas e são usadas principalmente na esterilização de produtos médicos e irradiação de alimentos, onde a penetração maior da radiação é uma vantagem ${ }^{(31,66)}$.

Os aceleradores de elétrons são geralmente preferidos como fonte de radiação para aplicações ambientais. Suas vantagens são: taxa de dose alta, rendimento maior de energia, licenciamento similar às máquinas de Raios$\mathrm{X}$ e o sistema liga-desliga que cessa a emissão da radiação ionizante. As desvantagens são: a penetração baixa dos elétrons e a necessidade de operadores especializados ${ }^{(33,66)}$.

Aceleradores de energia intermediária de $0,5 \mathrm{MeV}$ a $5,0 \mathrm{MeV}$ e potência do feixe de $300 \mathrm{~kW}$ a $350 \mathrm{~kW}$ são utilizados em muitas áreas de processamento por radiação como reticulação de polímeros, vulcanização de elastômeros e cura de tintas e vernizes. Aceleradores de alta energia, de $5 \mathrm{MeV}$ a $10 \mathrm{MeV}$ e potência do feixe acima de 100 kW, são usados na esterilização de produtos médicos-cirúrgicos e no processamento de alimentos ${ }^{(33)}$. 
O acelerador de elétrons é uma alternativa em aplicações ambientais, porque funciona a base de eletricidade e, de acordo com a finalidade, máquinas de pequeno porte podem ser construídas, facilitando o manuseio e o transporte para uso em diferentes locais podendo ser usado em associação com outras técnicas. A distribuição não homogênea da dose na camada irradiada tem sido resolvida com o desenvolvimento de sistemas de irradiação adequados ${ }^{(33,39,40)}$.

\subsection{Técnicas Analíticas para Agrotóxicos}

As técnicas analíticas mais adequadas para analisar os agrotóxicos são as cromatográficas, sendo a cromatografia gasosa, CG, a mais freqüentemente usada. Colunas capilares com desempenho alto, contendo fases estacionárias não-polares ou semipolares, principalmente com base de polisiloxano, são as mais utilizadas. Atualmente a CG associada com espectrometria de massa (CGMS) ou com tandem MS (CG/MS-MS) são freqüentemente empregadas para análise de mistura de agrotóxicos. No caso de confirmação de agrotóxicos específicos, são utilizados os detectores de captura de elétrons (DCA), nitrogênio-fósforo (DNF) e ionização de chama (DIC) $(5,14,18,65)$

De acordo com o tipo do agrotóxico utiliza-se um tipo diferente de coluna, para os organoclorados utiliza-se a coluna capilar de sílica fundida com dimensões variando entre 10 e 60 metros, diâmetro interno entre 0,1 a 0,53 mm e com filme de 0,3 $\mu \mathrm{m}$ de espessura da fase estacionária apolar. Estas colunas possuem nomes comerciais diferentes de acordo com o fabricante, como as dos tipos DB1, OV1, SE30, HP1, CPSIL 5CB, e OV11 (100\% dimetil polissiloxano). 
Para os orfanofosforados utiliza-se a coluna capilar de sílica fundida com dimensões entre 10 e $60 \mathrm{~m}$, diâmetro interno de 0,1 a 0,53 mm e com filme de $0,5 \mu \mathrm{m}$ de espessura da fase estacionária semi polar,iguais as do tipo OV17, DB17, HP17, SPB50 e CPSIL 24CB (fenil metil polissiloxano - 50\% fenil).

Vários métodos foram desenvolvidos para determinar diferentes grupos de inseticidas usando diferentes solventes para extração em diferentes

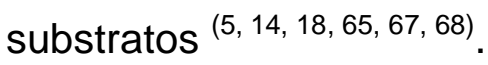

\subsection{Objetivo}

O objetivo do presente trabalho é avaliar a transferência da contaminação de embalagens de agrotóxicos para o solo e a remoção desta contaminação utilizando a radiação ionizante proveniente de uma fonte de ${ }^{60} \mathrm{Co}$. 


\section{PARTE EXPERIMENTAL}

A parte experimental será descrita considerando-se as três etapas do trabalho, que foram a amostragem, a contaminação com agrotóxicos, o processamento por radiação ionizante e a análise dos agrotóxicos presentes no solo.

\subsection{Amostragem}

Foram coletados dois tipos de solos distintos. Um no Instituto de Pesquisas Energéticas e Nucleares (IPEN) na cidade de São Paulo e outro na região de Piracicaba, numa área de plantação de cana-de-açúcar. Ambos foram coletados a $30 \mathrm{~cm}$ da superfície e área de $1,0 \mathrm{~m}^{2}$, foram peneirados com malha de 2,0 mm de diâmetro e transferidos para recipientes plásticos e fechados em temperatura ambiente e sem contato com luz.

\subsubsection{Caracterização dos solos}

Os ensaios de textura e matéria orgânica do solo, foram realizados no Laboratório de Solos do CQMA-IPEN e a concentração dos metais e óxidos metálicos foram realizadas pelo Laboratório de Fluorescência de Raios-X do CQMA-IPEN.

Para a determinação da textura e a massa orgânica utilizou-se a metodologia adotada pelo laboratório de física de solo do IPT, foi utilizado o método do densímetro Boyoucos ${ }^{(73)}$

\section{- Preparação do solo para determinação da textura e matéria orgânica}

Pesou-se $300 \mathrm{~g}$ de solo de cada tipo e espalhou-se em uma bandeja de aço inox, para secagem ao ar por 48 horas, em local livre de contaminação e protegido de correntes de ar. Os torrões foram desagregados utilizando um destorrador e passado na peneira com 2,0 mm de diâmetro dos furos. Após 
este processo foi realizado o quarteamento das amostras para obter duplicatas uniformes para os testes de caracterização (granulometria) e quantidade de massa orgânica.

\section{- Preparo do dispersante:}

$\mathrm{O}$ dispersante foi preparado, dissolvendo-se $4 \mathrm{~g}$ de $\mathrm{NaOH}$ com aproximadamente $30 \mathrm{~mL}$ de água deionizada num béquer de $150 \mathrm{~mL}$, adicionou-se $10 \mathrm{~g}$ de hexametafosfato de sódio (HMP) e agitou-se com um bastão de vidro, adicionou-se mais água deionizada e agitou-se mecanicamente durante meia hora e diluiu-se a $1000 \mathrm{~mL}$ em balão volumétrico de $1000 \mathrm{ml}$.

\section{- Preparo da amostra:}

Pesou-se $50 \mathrm{~g}$ de solo num erlenmeyer de $500 \mathrm{~mL}$, adicionou-se $250 \mathrm{ml}$ de dispersante, agitou-se durante 16 horas no agitador horizontal (shaker) em 170 rpm. A solução obtida foi transferida para uma proveta de $1000 \mathrm{~mL}$ e o completou-se o volume com água da torneira até 1000. A solução "branco" foi preparado numa proveta de $1000 \mathrm{~mL}$ com $250 \mathrm{~mL}$ de dispersante químico adicionando água de torneira até completar $1000 \mathrm{~mL}$. A temperatura e densidade foram medidos utilizando-se o densímetro de Boyoucos (este densímetro fornece a quantidade de argila e silte em gramas). A leitura no densímetro foi feita em 40 s e $2 \mathrm{~h}$ e foi calculado a \% de argila, silte e areia conforme as equações 1, 2 e 3 e utilizado diagrama de repartição de classes generalizadas de textura, apresentado na Figura $2^{(63)}$.

Equação 8. Porcentagem de Argila

$$
\% \text { Argila }=\frac{\text { leitura } 2 h-\text { leitura do branco }}{50} * 100
$$

Equação 9. Porcentagem de Silte

$$
\% \text { Silte }=\frac{(\text { leitura } 40 s-\text { leitura do branco })-(\text { leitura } 2 h-\text { leitura do branco })}{50} * 100
$$


Equação 10. Porcentagem de areia

$$
\% \text { Areia }=100-\% \text { Argila }-\% \text { Silte }
$$

\section{- Determinação da matéria orgânica (MO):}

Para determinação da matéria orgânica adotou-se a metodologia baseada na norma NBR $13600^{(8)}$ da ABNT. Pesou-se $5 \mathrm{~g}$ de solo na cápsula de porcelana, que foi levado à estufa a $110^{\circ} \mathrm{C}$ por duas horas. Pesou-se a cápsula após resfriar por 15 minutos. Levou-se a cápsula à mufla a temperatura de $375^{\circ} \mathrm{C}$ por quatro horas. Retirou-se a cápsula da mufla e após 15 minutos pesou-se e calculou-se a \% de matéria orgânica conforme equação 11 .

Equação 11. Porcentagem de massa orgânica.

$\% M O=\frac{\text { massa do solo seco na estufa }- \text { massa do solo queimado na mufla }}{\text { massa do solo } \sec o \text { na estufa }} \times 100$

Para determinação do $\mathrm{pH}$, foi utilizado a metodologia segundo a NBR10.005. Para determinação da densidade aparente foi utilizado a metodologia segundo NBR10004 e a umidade foi determinada com base no peso constante, onde as amostras de dos solos foram colocados em estufa à $105^{\circ} \mathrm{C}$ e pesado as amostras $2 \mathrm{em} 2$ horas.

\subsection{Montagem das colunas e lixiviação do solo}

O sistema de contaminação constou de dez tubos de PVC (distribuídos em série conforme tabela 1) com $5,0 \mathrm{~cm}$ de diâmetro, na extremidade inferior foi colocado um tecido poroso (para sustentar o solo e passar a água lixiviada). Preencheu-se o tubo com $1000 \mathrm{~g}$ de amostra de solo do IPEN e $1200 \mathrm{~g}$ do solo de Piracicaba (devido diferença de densidade) e na 
parte superior colocou-se 40,0 $\mathrm{g}$ de amostras de embalagens contaminadas com agrotóxicos (diversos tipos) cortados em área de aproximadamente 0,5 $\mathrm{cm}^{2}$ e cobriu-se com algodão (para garantir que o gotejamento de água destilada fosse distribuído em toda área do tubo) (Fig.2).

O gotejamento de água destilada se deu com uma mangueira com diâmetro de 1,27 cm (passando por todos os tubos) e uma agulha de seringa estancada na mangueira para ocorrer o gotejamento em cada tubo. Foi utilizada garrafa pet cortada para coletar água destilada lixiviada na base inferior do tubo (Figura 3). O gotejamento de água destilada levou por 14 dias, alternando os dias com um volume médio de $145,0 \mathrm{~cm}^{3}$ por $2 \mathrm{~h}$, totalizando $1015,0 \mathrm{~cm}^{3} \mathrm{em}$ cada tubo. As adições de água destiladas foram interrompidas por identificar resíduo de agrotóxico na água lixiviada por análise de Carbono Orgânico Total (COT).

Tabela 1. Distribuição do solo e agrotóxico no sistema de simulação de contaminação.

\begin{tabular}{|c|c|c|c|}
\hline $\begin{array}{l}\text { Número } \\
\text { do tubo }\end{array}$ & $\begin{array}{c}\text { Tipo de } \\
\text { solo }\end{array}$ & $\begin{array}{l}\text { Massa } \\
\text { de } \\
\text { Solo } \\
\text { (g) }\end{array}$ & $\begin{array}{c}\text { Massa } \\
\text { de embalagens } \\
\text { contaminadas } \\
\text { (g) }\end{array}$ \\
\hline 0 & Sem solo & 0 & 40,0 \\
\hline 1 & Média & 1.000 & 40,0 \\
\hline 2 & “ & 1.000 & 40,0 \\
\hline 3 & “ & 1.000 & 0 \\
\hline 4 & “ & 1.000 & 0 \\
\hline 5 & M.Argilosa & 1.200 & 40,0 \\
\hline 6 & “ & 1.200 & 40,0 \\
\hline 7 & “ & 1.200 & 0 \\
\hline 8 & “ & 1.200 & 40,0 \\
\hline 9 & “ & 1.200 & 0 \\
\hline
\end{tabular}




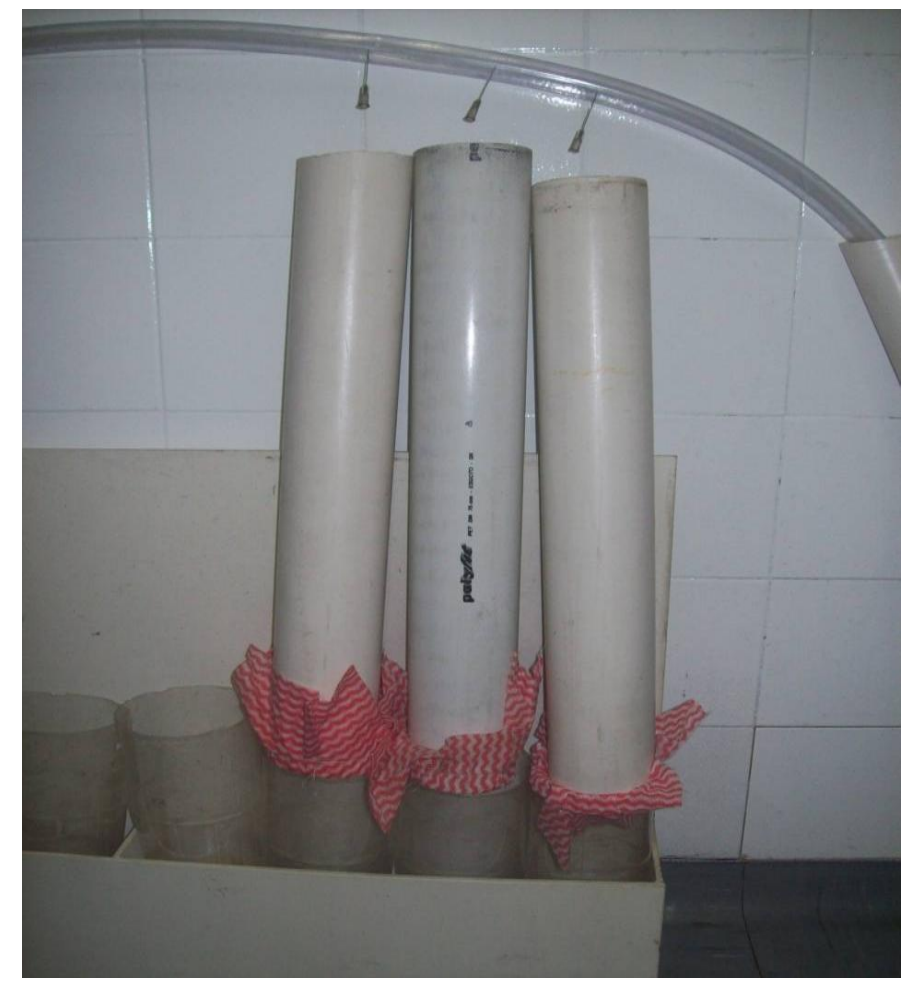

Figura 2. Parte do sistema de contaminação dos solos com tubos de PVC e gotejamento de água.

Após esse período a altura do tubo contendo amostra de solo foi dividida em três partes iguais (denominadas $A, B$ e $C$ ), cada parte foi homogeneizada e distribuída em frascos de vidro contendo 30,0 g de amostra em cada um e o teor de umidade em cada camada foi determinado. 


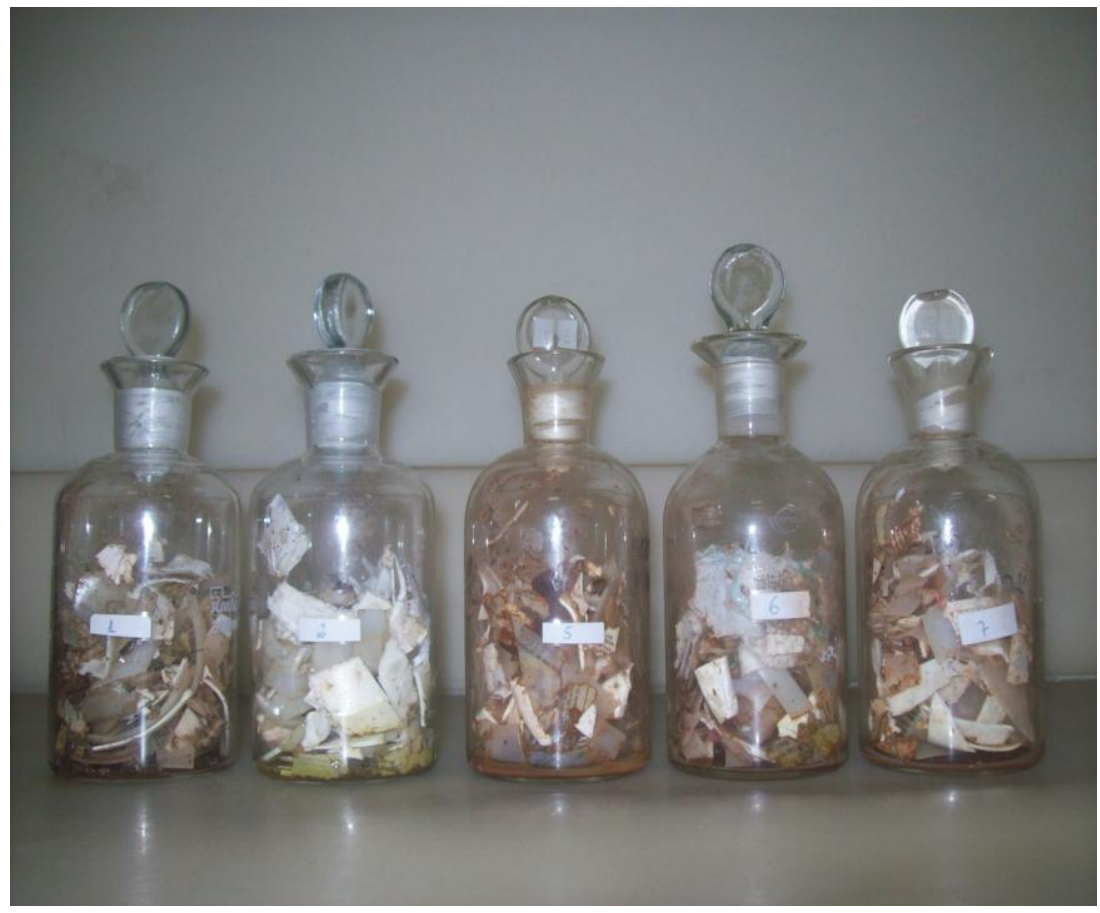

Figura 3. Mistura de embalagens após a contaminação dos solos.

As amostras foram analisadas por cromatografia gasosa (CG), em triplicata para verificar a distribuição dos agrotóxicos ao longo do tubo. Nas amostras restantes foi adicionado $10,0 \mu \mathrm{L}$ de solução padrão $\left(10.000 \mathrm{mg} \cdot \mathrm{L}^{-1}\right.$ de Ametrina e $48.000 \mathrm{mg} \cdot \mathrm{L}^{-1}$ Clorpirifos) e submetidas à irradiação gama.

\subsection{Irradiação das amostras de solos}

Os frascos com $30 \mathrm{~g}$ de solo contaminado foram irradiados em temperatura ambiente na fonte de Co-60 do tipo Gammacell com taxa de dose de $3.5 \mathrm{kGy} / \mathrm{h}$, e dosímetro do tipo "Perspex" foi empregado para dosimetria do sistema. As doses absorvidas aplicadas foram 5 kGy, 10 kGy, 20 kGy e 30 kGy. As amostras foram irradiadas em triplicata. 


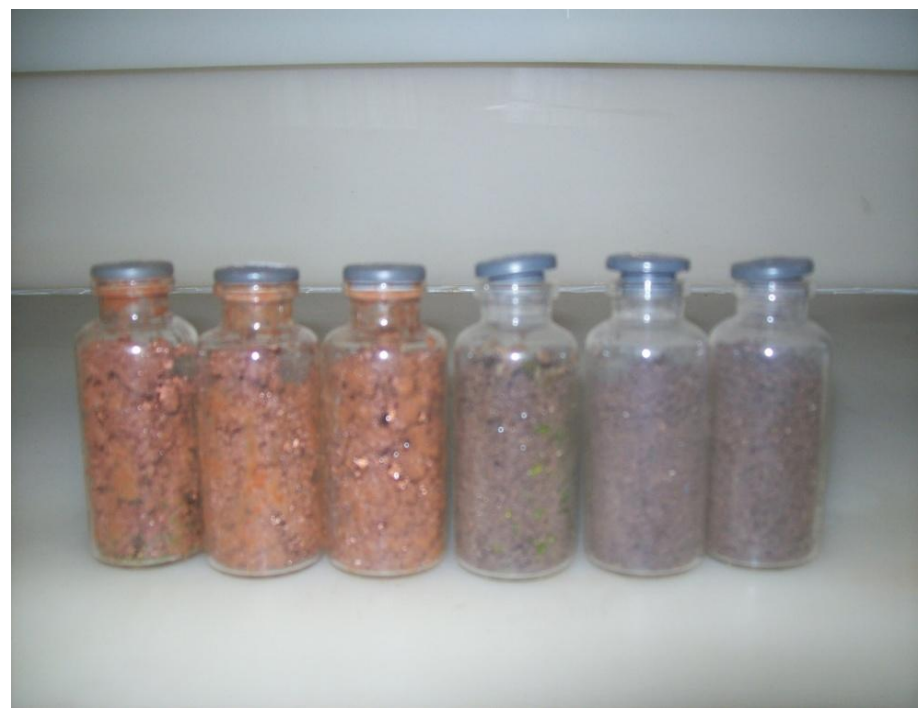

Figura 4. Amostras preparadas para irradiação gama e análise cromatográfica.

\subsection{Análise de agrotóxicos em amostras de solos}

Após a irradiação os agrotóxicos foram extraídos com $5 \mathrm{ml}$ de hexano/dichloromethano1:1 $\mathrm{v} / \mathrm{v}$, adicionado diretamente no frasco usando um sistema de ultrassom por 30 minutos. A área dos picos dos agrotóxicos foram determinadas por cromatografia a gás utilizando GC-FID 17-A da Shimadzu, com coluna DB5 ( $30 \mathrm{~m} \times 0,25 \mathrm{~mm}$ I.D.), temperatura da coluna: $50^{\circ} \mathrm{C}$ por 10 min., sendo elevada a $150^{\circ} \mathrm{C}, 10^{\circ} \mathrm{C} / \mathrm{min}$. Após, foi elevada a $300^{\circ} \mathrm{C}$, sendo a elevação de $15^{\circ} \mathrm{C} / \mathrm{min}$., mantida por 5 minutos. Temperatura de injeção: $200^{\circ} \mathrm{C}$. Temperatura de detecção: $300^{\circ} \mathrm{C}$. Fluxo: $10 \mathrm{~mL} / \mathrm{min}$., N2. Pressão de controle (EPC): $37 \mathrm{kPa}$. Para extração foi utilizado solvente orgânico de hexano e diclorometano $(1: 1 \mathrm{v} / \mathrm{v})$ e submetido às amostras por 5 min de agitação mecânica, 10 min. no ultra-som e centrifugado por 5 min a 1000 rpm. 


\section{RESULTADOS E DISCUSSÕES}

Os resultados serão apresentados em três etapas que são a caracterização dos solos, a caracterização da contaminação e a avaliação da eficiência do processamento por radiação ionizante.

\subsection{Caracterização dos solos}

Os resultados obtidos com os teores de silte, argila e areia (Tabela 2), foram confrontados com diagrama de repartição o diagrama de repartição de classes generalizadas de textura, da EMBRAPA ${ }^{(33)}$, apresentado na Figura 3 e, dessa forma, os solos foram classificados segundo a textura. Foi constatado que o solo amostrado no IPEN é um solo com textura média e o solo amostrado em Piracicaba é um solo de textura muito argilosa.

Tabela 2. Caracterização dos solos amostrados e parâmetros físico-químico.

\begin{tabular}{ccccccc}
\hline Amostra & $\begin{array}{c}\text { Silte } \\
(\%)\end{array}$ & $\begin{array}{c}\text { Argila } \\
(\%)\end{array}$ & $\begin{array}{c}\text { Areia } \\
(\%)\end{array}$ & $\begin{array}{c}\text { Massa Orgânica } \\
(\%)\end{array}$ & $\begin{array}{c}\text { Densidade } \\
\text { Aparente } \\
{\mathrm{g} . \mathrm{cm}^{-3}}^{*}\end{array}$ & $\mathbf{p H}$ \\
\hline $\begin{array}{c}\text { Textura Muito } \\
\text { Argilosa }\end{array}$ & 9,0 & 65,0 & 26,0 & 2,1 & 0,81 & 6,7 \\
Textura Média & 5,0 & 32,0 & 63,0 & 8,2 & 0,71 & 4,9 \\
\hline
\end{tabular}




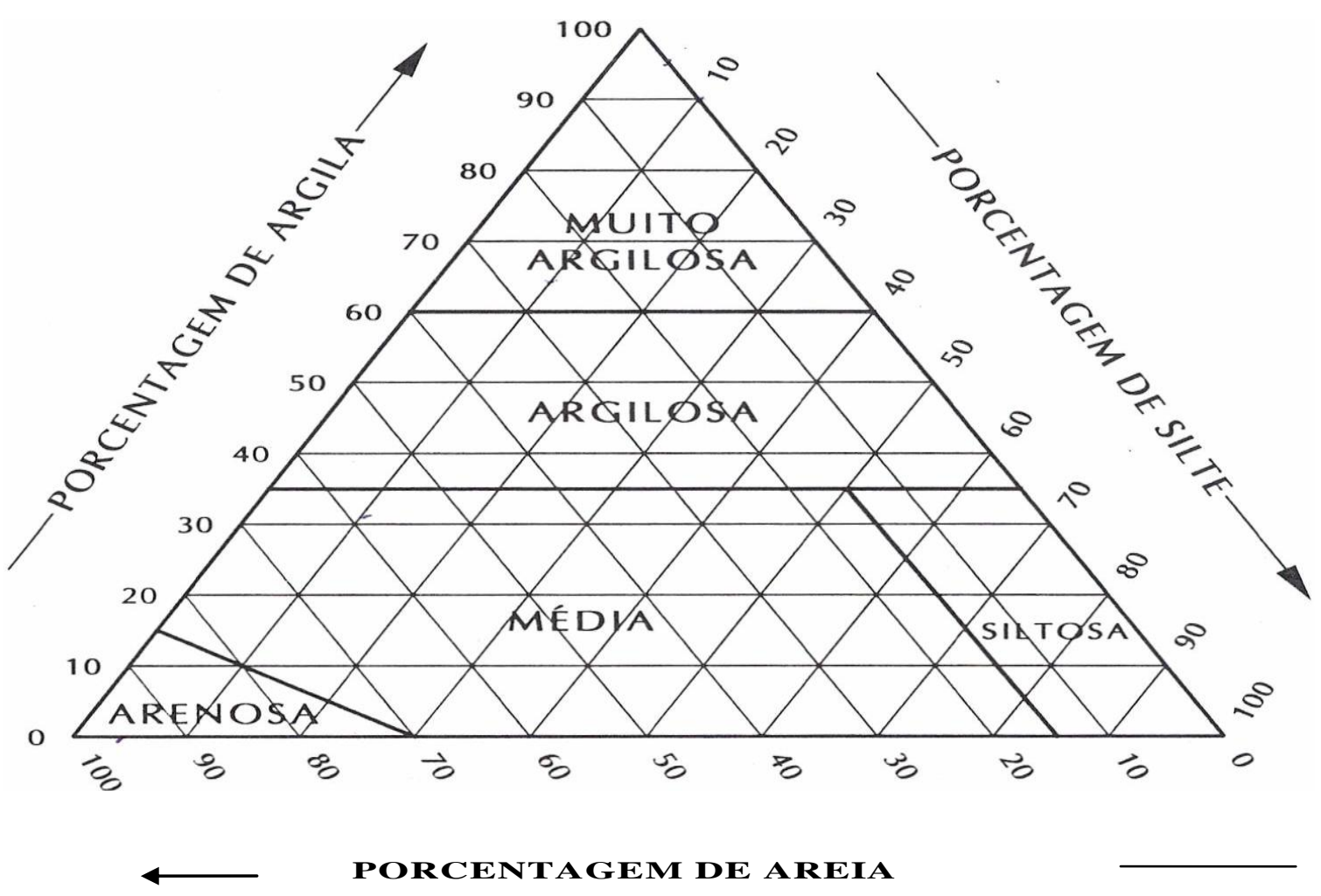

Figura 5. Diagrama de repartição de classes generalizadas de textura ${ }^{(31)}$

Os resultados dos teores de metais, analisado por fluorescência de raios-X são apresentados na Tabela 3 . O solo de textura muito argilosa apresentou concentrações mais elevadas de $\mathrm{Al}_{2} \mathrm{O}_{3}$ e $\mathrm{Fe}_{2} \mathrm{O}_{3}$ e menores de $\mathrm{SiO}_{2}$ do que o solo de textura média. De acordo com a literatura, verifica-se que, em geral, solo de textura muito argilosa tem capacidade de retenção de matéria inorgânica maior do que solo de textura média, principalmente os minerais secundários especialmente $\mathrm{Al}_{2} \mathrm{O}_{3}$ e $\mathrm{Fe}_{2} \mathrm{O}_{3}{ }^{(17)}$. 
Tabela 3. Teores dos óxidos metálicos nos dois tipos de solos

\begin{tabular}{|ccc|}
\hline Óxidos & $\begin{array}{c}\text { Solo de } \\
\text { textura } \\
\text { Muito } \\
\text { Argilosa } \\
(\%)\end{array}$ & $\begin{array}{c}\text { Solo de Textura } \\
\text { Média } \\
(\%)\end{array}$ \\
\hline $\mathrm{SiO}_{2}$ & 46,24 & 56,32 \\
$\mathrm{Al}_{2} \mathrm{O}_{3}$ & 27,07 & 24,06 \\
$\mathrm{Fe}_{2} \mathrm{O}_{3}$ & 12,86 & 5,99 \\
$\mathrm{TiO}_{2}$ & 2,31 & 1,20 \\
$\mathrm{~K}_{2} \mathbf{O}$ & 0,80 & 1,01 \\
$\mathbf{C a O}$ & 0,20 & 0,32 \\
$\mathbf{M g O}$ & 0,47 & 0,20 \\
$\mathbf{S O}$ & 0,04 & 0,15 \\
\hline
\end{tabular}

Os resultados de $\mathrm{pH}$, densidade e umidade das amostras dos dois solos estudados são apresentados na Tabela 4. O solo de textura argilosa possui grande quantidade de óxidos de alumínio e de ferro, formam pequenos grãos semelhantes ao pó-de-café, isso lhe dá um aspecto similar ao arenoso, conseqüentemente maior densidade aparente e também proporciona tempo maior de interação do agrotóxico com o solo dificultando a extração do mesmo. $\mathrm{O} \mathrm{pH}$ do solo de textura média é menor que o do solo de textura muito argilosa, isso ocorre pela maior quantidade de matéria orgânica presente no solo de textura média.

Tabela 4. Parâmetros físico-químicos dos solos

\begin{tabular}{ccccccc}
\hline Amostra & $\begin{array}{c}\text { Silte } \\
(\%)\end{array}$ & $\begin{array}{c}\text { Argila } \\
(\%)\end{array}$ & $\begin{array}{c}\text { Areia } \\
(\%)\end{array}$ & $\begin{array}{c}\text { Massa Orgânica } \\
(\%)\end{array}$ & $\begin{array}{c}\text { Densidade } \\
\text { Aparente } \\
\mathrm{g.cm}^{-3}\end{array}$ & $\mathbf{p H}$ \\
\hline $\begin{array}{c}\text { Textura Muito } \\
\text { Argilosa }\end{array}$ & 9,0 & 65,0 & 26,0 & 2,1 & 0,81 & 6,7 \\
Textura Média & 5,0 & 32,0 & 63,0 & 8,2 & 0,71 & 4,9 \\
\hline
\end{tabular}




\subsection{Caracterização da Contaminação}

$\mathrm{Na}$ Figura 6 é apresentado o cromatograma com os principais agrotóxicos presentes nas amostras de embalagens contaminadas. O herbicida atrazina estava presente em concentração bem mais elevada que os demais, seguida pelo herbicida trifluralin e pelo inseticida metilparation. Na Tabela 5 são apresentadas as principais características desses agrotóxicos. Como essas amostras de embalagens são originadas do Centro de Recolhimento de Embalagens de Piracicaba, elas dão uma idéia interessante do perfil de consumo de agrotóxicos na região, que está de acordo com o consumo de agrotóxicos no Brasil, apresentado na introdução deste trabalho (Figura 1). Ou seja, o maior consumo é de herbicidas, seguido por fungicidas e inseticidas. O Naftaleno, Nitrofeno e Ácido benzenodicarboxilico não são agrotóxicos, mas solventes utilizados na formulação comercial.

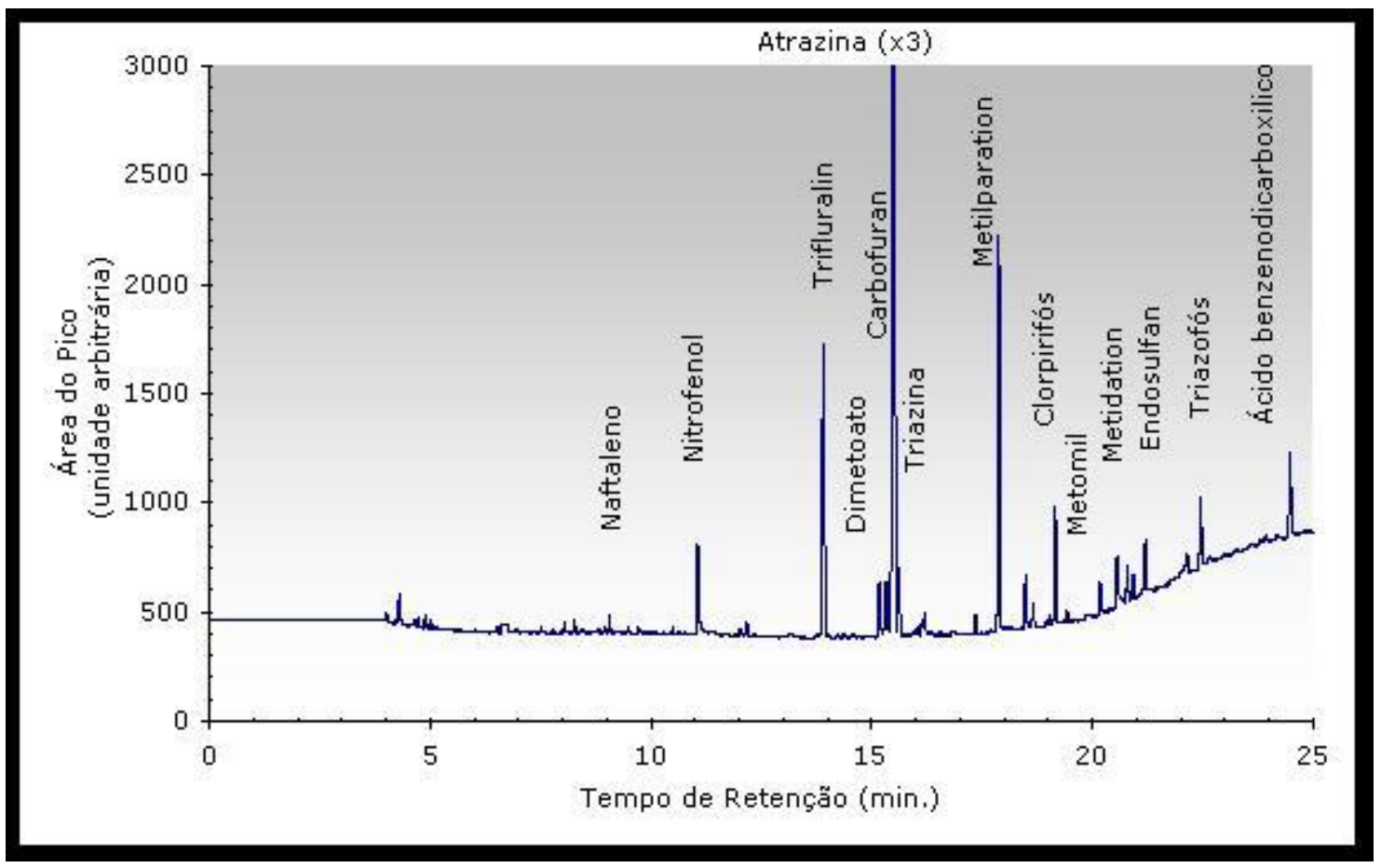

Figura 6 Cromatograma mostrando os principais agrotóxicos presentes na mistura de embalagens picadas 
TABELA 5. Caracterização dos principais agrotóxicos identificados na mistura de embalagens contaminadas ${ }^{(38)}$

\begin{tabular}{|c|c|c|c|c|c|}
\hline $\begin{array}{c}\text { Nome } \\
\text { Comercial }\end{array}$ & Nome Químico & Tipo de Ação & $\begin{array}{l}\text { Solubilidade } \\
\text { em água } \\
\left.\text { (mg. } \mathrm{L}^{-1}\right)\end{array}$ & $\begin{array}{c}\text { Persistência } \\
\text { no Solo }\end{array}$ & pH \\
\hline Atrazina & $\begin{array}{c}\text { 2-cloro-4-(2- } \\
\text { propilamino)-6- } \\
\text { etilamino-s-triazina }\end{array}$ & Herbicida- triazina & 33 & Alta & $1.0-5.0$ \\
\hline Ametrina & $\begin{array}{c}\mathrm{N} \text {-2-etil-N-4-isopropil-6- } \\
\text { metiltio-1,3,5-triazina- } \\
\text { 2,4-diamina } \\
\end{array}$ & Herbicida- triazina & 200 & Alta & 3.5 \\
\hline Carbofuran & $\begin{array}{l}\text { 7-Benzofuranol. 2.3- } \\
\text { diidro-2.2-dimetil- } \\
\text { metilcarbamato }\end{array}$ & $\begin{array}{c}\text { Inseticida, } \\
\text { acaricida } \\
\text { Benzofuran } \\
\text { Metilcarbamato }\end{array}$ & 320 & Curta & 3.5 \\
\hline Clorpirifos & $\begin{array}{l}\text { O.O-Dietil-O-(3.5.6- } \\
\text { tricloro-2-piridil) } \\
\text { fosforotioato }\end{array}$ & $\begin{array}{c}\text { Inseticida, } \\
\text { acaricida } \\
\text { Organofosforado }\end{array}$ & 2 & Curta & $4.5-7.0$ \\
\hline Dimetoato & $\begin{array}{l}\text { O.O-dimetil S-metil } \\
\text { carbamoil metil } \\
\text { fosforoditioato }\end{array}$ & $\begin{array}{c}\text { Inseticida, } \\
\text { acaricida } \\
\text { Organofosforado }\end{array}$ & 25 & Curta & $3.5-6.5$ \\
\hline Endosulfan & $\begin{array}{c}\text { hexaclorohexahidrometa } \\
\text { no-2-3-4- } \\
\text { benzodioxatienpin-3- } \\
\text { oxido } \\
\end{array}$ & $\begin{array}{l}\text { Inseticida, } \\
\text { acaricida } \\
\text { Clorodieno }\end{array}$ & 330 & Media & $6.0-8.0$ \\
\hline Metomil & $\begin{array}{l}\text { S-metil-N- } \\
\text { (metilcarbamoiloxi)- } \\
\text { tioacetimidate }\end{array}$ & $\begin{array}{c}\text { Inseticida, } \\
\text { acaricida } \\
\text { Oxima } \\
\text { metilcarbamato }\end{array}$ & 500 & Media & 6.3 \\
\hline Metidation & $\begin{array}{c}\text { S-2.3-dihidro-5-metoxi- } \\
\text { 2-oxo-1.3.4-tiadiazol-3- } \\
\text { ilmetil O.O- } \\
\text { dimetilfosforoditioate }\end{array}$ & $\begin{array}{c}\text { Inseticida, } \\
\text { acaricida } \\
\text { Organofosforado }\end{array}$ & 220 & Media & 5 \\
\hline Metilparation & $\begin{array}{l}\text { O.O-dimetil-O-0- } \\
\text { nitrofenil fosforodioato }\end{array}$ & $\begin{array}{c}\text { Inseticida, } \\
\text { acaricida } \\
\text { Organofosforado }\end{array}$ & 60 & Curta & 7 \\
\hline Triazofos & $\begin{array}{l}\text { O.O-Dietil O-(1-fenil-1H- } \\
\text { 1.2.4-triazol-3-yl) } \\
\text { fosforotioato }\end{array}$ & $\begin{array}{c}\text { Inseticida, } \\
\text { acaricida } \\
\text { Organofosforado }\end{array}$ & 81 & NF & $1.8-3.8$ \\
\hline Trifluralina & $\begin{array}{l}\text { Benzenamina. 2.6- } \\
\text { dinitro-N.N-dipropil-4- } \\
\text { (trifluorometil) }\end{array}$ & $\begin{array}{c}\text { Herbicida } \\
\text { Dinitroanilina }\end{array}$ & 300 & Media & 5.5 \\
\hline
\end{tabular}

OBS: É considerado tempo de meia vida curta até 90 dias de persistência, media de 91 à 180 dias e longa de acima de 180 dias.

$\mathrm{Na}$ Tabela 6 é apresentado o esquema de contaminação do solo com os resultados de carbono orgânico total, COT e carbono inorgânico, $\mathrm{Cl}$, no 
lixiviado. Pode ser observado que houve maior lixiviação de compostos orgânicos no solo de textura tipo média que no do tipo argiloso. Quando a contaminação por agrotóxicos estava presente, houve um aumento médio no teor de COT nos dois tipos de solos. O carbono inorgânico, que representa os carbonatos, foi lixiviado em maior quantidade no solo de textura média.

Com esses dados é possível avaliar a porcentagem de material orgânico ficou retido no solo, que nesse caso é representada pelos agrotóxicos, que permaneceu retida após a contaminação. Para esse cálculo foi considerada a concentração de TOC na água após a lixiviação das embalagens sem solo que foi $34,2 \mathrm{mg} \cdot \mathrm{L}^{-1}$ de TOC, enquanto que o solo de textura média apresentou um valor médio de 28,0 mg. $\mathrm{l}^{-1}$ e subtraindo teremos o valor de agrotóxico lixiviado que corresponde $4,6 \mathrm{mg} . \mathrm{I}^{-1}$ dividindo pelo o que corresponderia $100 \%$ de lixiviação que é a embalagem sem solo $34,2 \mathrm{mg.l}^{-1}$, transformamos em porcentagem teremos $13,5 \%$ de agrotóxico lixiviado e $86,4 \%$ de agrotóxico retido no solo.

O solo de textura muito argilosa apresentou um valor médio, após a contaminação de $15,7 \mathrm{mg} . \mathrm{I}^{-1}$ de TOC o branco deste solo apresentou $9,7 \mathrm{mg} . \mathrm{I}^{-1}$ de material orgânico lixiviado, subtraindo teremos $6,0 \mathrm{mg}^{-1}{ }^{-1}$ dividindo pelo lixiviado da embalagem sem solo que corresponde à $34,2 \mathrm{mg}^{-1} \mathrm{I}^{-1} \mathrm{e}$ transformado em porcentagem teremos $17,5 \%$ de lixiviado e $82,5 \%$ de agrotóxico retido neste solo. 
Tabela 6. Carbono Orgânico Total (COT) e Carbono Inorgânico $(\mathrm{Cl})$ no lixiviado

\begin{tabular}{ccc}
\hline $\begin{array}{c}\text { Tipo de } \\
\text { amostra }\end{array}$ & $\begin{array}{c}\text { COT no } \\
\text { lixiviado } \\
\text { (mg. } \mathbf{L}^{-1} \text { ) }\end{array}$ & $\begin{array}{c}\text { IC } \text { no } \\
\text { lixiviado } \\
\text { (mg. } \mathbf{L}^{-1} \text { ) }\end{array}$ \\
\hline $\begin{array}{c}\text { Embalagem sem solo } \\
\text { Solo de textura Média com } \\
\quad \text { embalagem }\end{array}$ & 34,2 & 2,6 \\
$\begin{array}{c}\text { Solo de textura Média sem } \\
\text { embalagem }\end{array}$ & 28,0 & 16,8 \\
$\begin{array}{c}\text { Solo de textura Argilosa com } \\
\text { embalagem }\end{array}$ & 23,4 & 18,1 \\
$\begin{array}{c}\text { Solo de textura Argilosa sem } \\
\text { embalagem }\end{array}$ & 15,7 & 17,2 \\
\hline
\end{tabular}

Nas Figuras 7a e 7b são apresentados os resultados das análises de caracterização dos agrotóxicos que permaneceram nas embalagens após o período de lixiviação. A variação nas concentrações que restaram nas embalagens correspondentes a cada tipo de solo pode ser considerada pequena por ser um trabalho experimental, o que indica que houve homogeneidade na transferência de agrotóxicos para os diferentes tipos de solos. A Embalagem total corresponde à mistura de agrotóxico sem lixiviação (40g de embalagem cortada).

$\mathrm{Na}$ Tabela 7 são apresentadas as porcentagens de agrotóxicos que foram lixiviados pela água. As embalagens correspondentes aos tubos $1 \mathrm{e}$ 2 apresentaram as maiores transferências, principalmente no caso dos agrotóxicos metilparation (56\%), metomil (62\%). Considerando a média de transferências, as maiores formam de metilparation e metomil ( $>40 \%)$ e as menores foram de metidation e atrazina $(<30 \%)$. Calculado em função da embalagem total, ou seja, sem ser submetida à lixiviação. 


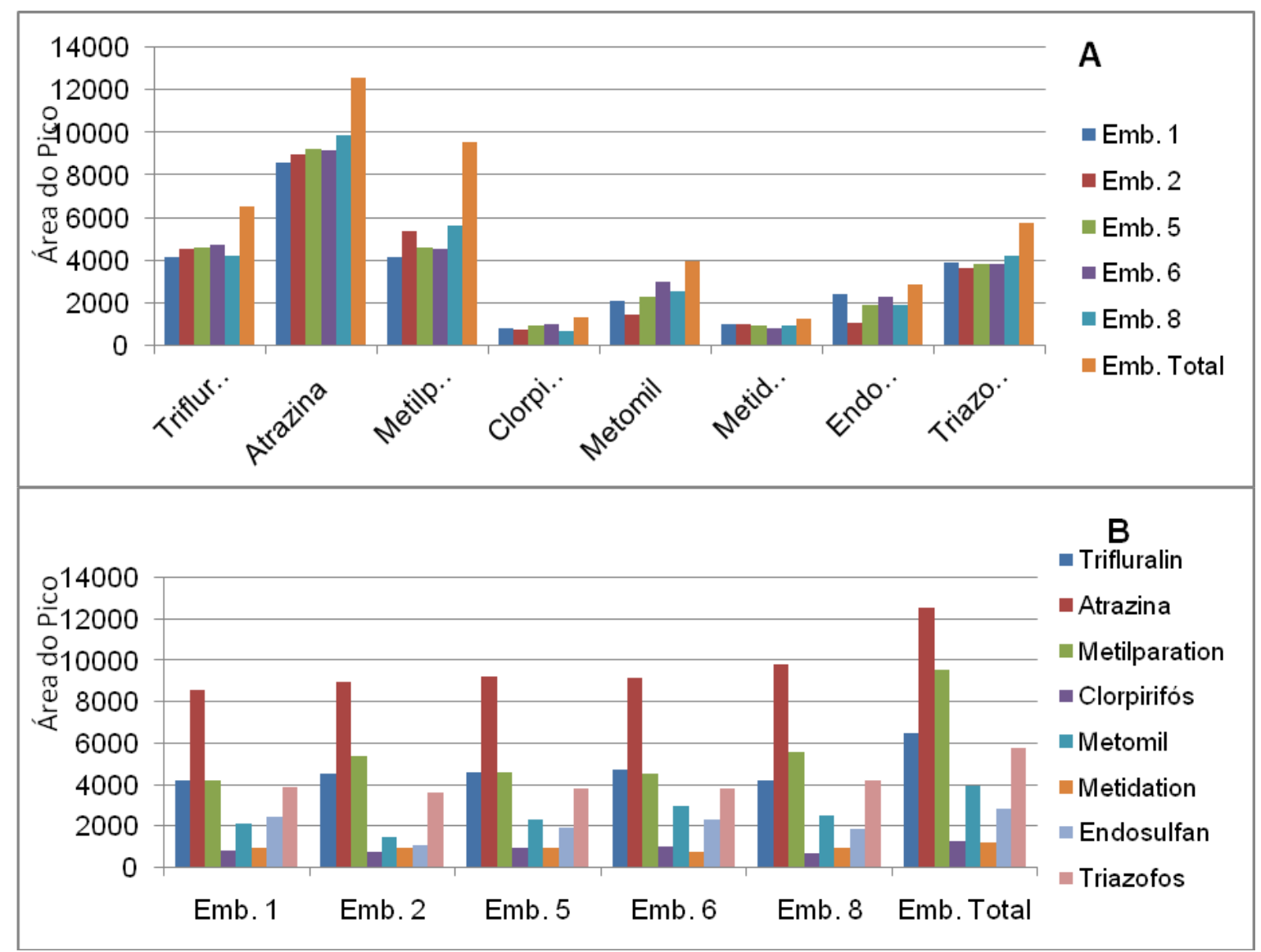

Figura 7 Variação da concentração dos agrotóxicos que restaram nas embalagens após o processo de lixiviação: "A" perfil de cada agrotóxico e "B" perfil de cada amostra de embalagem.

Tabela 7. Fração de cada agrotóxico que foi lixiviada pela água em cada tubo

\begin{tabular}{|l|r|r|r|r|r|r|}
\hline \multirow{2}{*}{ Agrotóxico } & $\begin{array}{c}\text { Emb. } \\
\mathbf{1}\end{array}$ & $\begin{array}{c}\text { Emb. } \\
\mathbf{2}\end{array}$ & $\begin{array}{c}\text { Emb. } \\
\mathbf{5}\end{array}$ & $\begin{array}{c}\text { Emb. } \\
\mathbf{6}\end{array}$ & $\begin{array}{c}\text { Emb. } \\
\mathbf{8}\end{array}$ & Média \\
\cline { 2 - 7 } & \multicolumn{7}{|c|}{$\mathbf{0}$} \\
\hline Trifluralin & 36 & 30 & 29 & 28 & 35 & 31,3 \\
Atrazina & 32 & 28 & 27 & 27 & 22 & 27,1 \\
Metilparation & 56 & 43 & 51 & 52 & 41 & 48,8 \\
Clorpirifós & 37 & 43 & 25 & 21 & 48 & 34,7 \\
Metomil & 46 & 62 & 41 & 24 & 35 & 41,6 \\
Metidation & 20 & 21 & 22 & 35 & 24 & 24,4 \\
Endosulfan & 15 & 61 & 33 & 20 & 34 & 32,6 \\
Triazofos & 33 & 36 & 33 & 33 & 26 & 32,3 \\
& & & & & & \\
\hline
\end{tabular}




\subsubsection{Distribuição dos agrotóxicos nas camadas de solos}

Após a separação das camadas de solos, que foram denominadas "A", "B" e "C", determinou-se o teor de umidade em cada camada e os resultados são apresentados na Tabela 7. Como esperado houve um acúmulo de água nas camadas inferiores e dessa forma a camada "A", que representa a parte inferior do tubo ficou mais úmida nos dois casos. Esta umidade é importante, pois aumenta a eficiência do processamento por radiação que, interagindo com as moléculas de água, levarão á formação de radicais hidroxilas altamente oxidantes

Tabela 8. Teor de umidade nas amostras das diferentes camadas de cada tipo de solo

\begin{tabular}{cccc}
\hline \multirow{2}{*}{ Amostra } & \multicolumn{3}{c}{ Umidade na camada (\%) } \\
& A & B & C \\
\hline $\begin{array}{c}\text { Textura Muito. } \\
\text { Argilosa }\end{array}$ & $27,7 \pm 1,2$ & $24,0 \pm 1,0$ & $22,7 \pm 0,7$ \\
Textura Média & $36,0 \pm 0,5$ & $30,1 \pm 0,5$ & $28,2 \pm 0,7$ \\
\hline
\end{tabular}

Por análise cromatográfica das amostras das três camadas do solo de textura média foram detectados os agrotóxicos: trifluralina, atrazina, metilparation, metomil, endosulfan e triazofós. Na Figura 8a é apresentada a distribuição destes agrotóxicos nas diferentes camadas e na Figura 8b é apresentada a distribuição dos agrotóxicos por camada. Os agrotóxicos presentes em concentrações mais elevadas foram a atrazina e o triazofós. A camada "A", mais úmida, foi a que apresentou as concentrações mais elevadas dos agrotóxicos. 


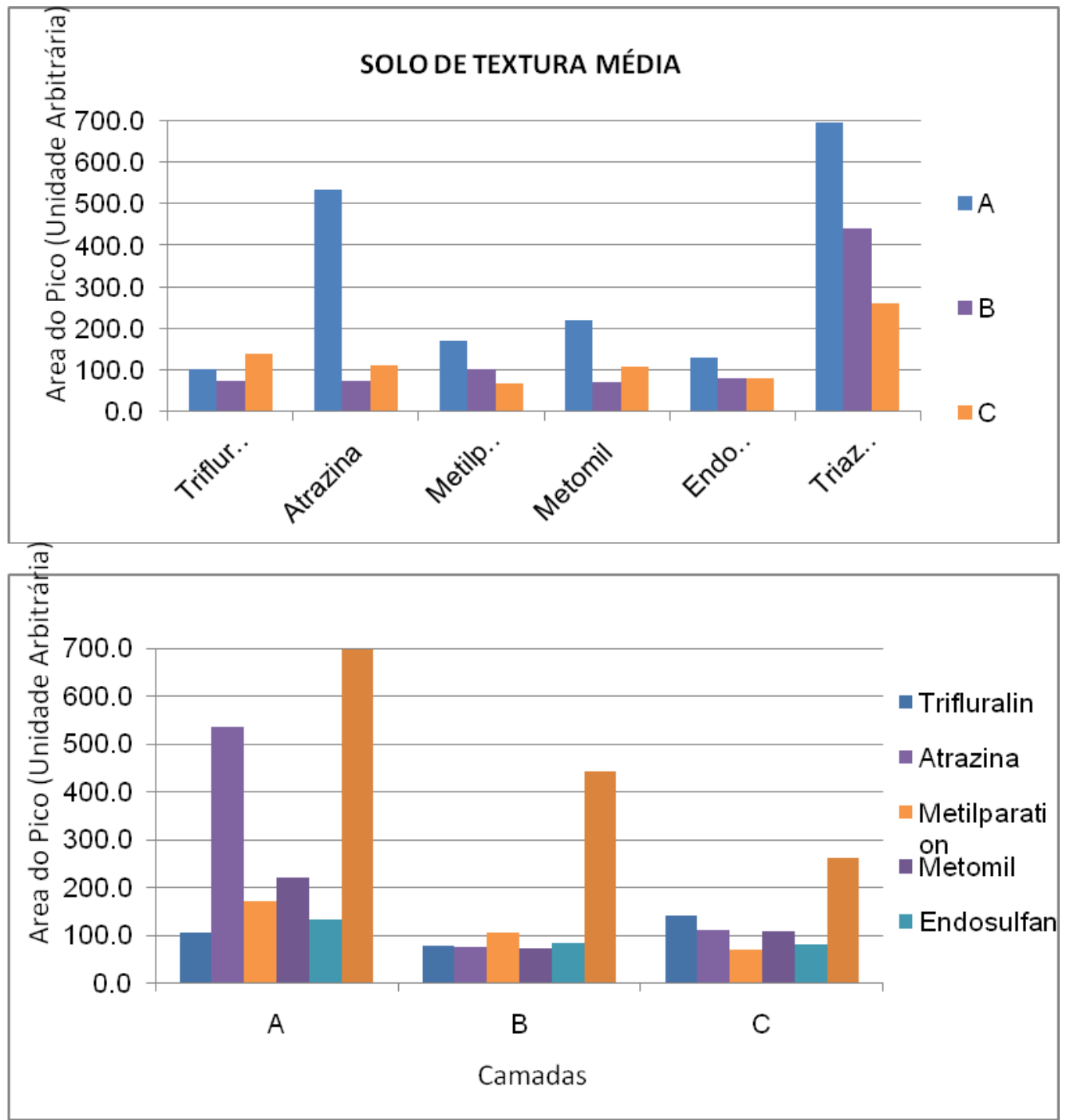

Figura 8 Perfil de distribuição por agrotóxico nas camadas e distribuição dos agrotóxicos em cada camada do solo de textura média

No caso do solo de textura muito argilosa, após análises cromatográficas de amostras das diferentes camadas, foram detectados os agrotóxicos trifluralina, atrazina, metilparation e metomil. Na Figura 9a e 9b são apresentadas as distribuições desses agrotóxicos por camada do solo argiloso e perfil de cada camada, respectivamente. Assim como no caso do solo de textura média a camada inferior "A" concentrou mais os agrotóxicos, com exceção do metilparation que apresentou maior concentração na camada "B". Nesse solo a trifluralina e o metilparation estiveram presentes em maiores concentrações que 
a atrazina e o metomil. Não foi detectado agrotóxico no solo sem a embalagem de agrotóxicos.
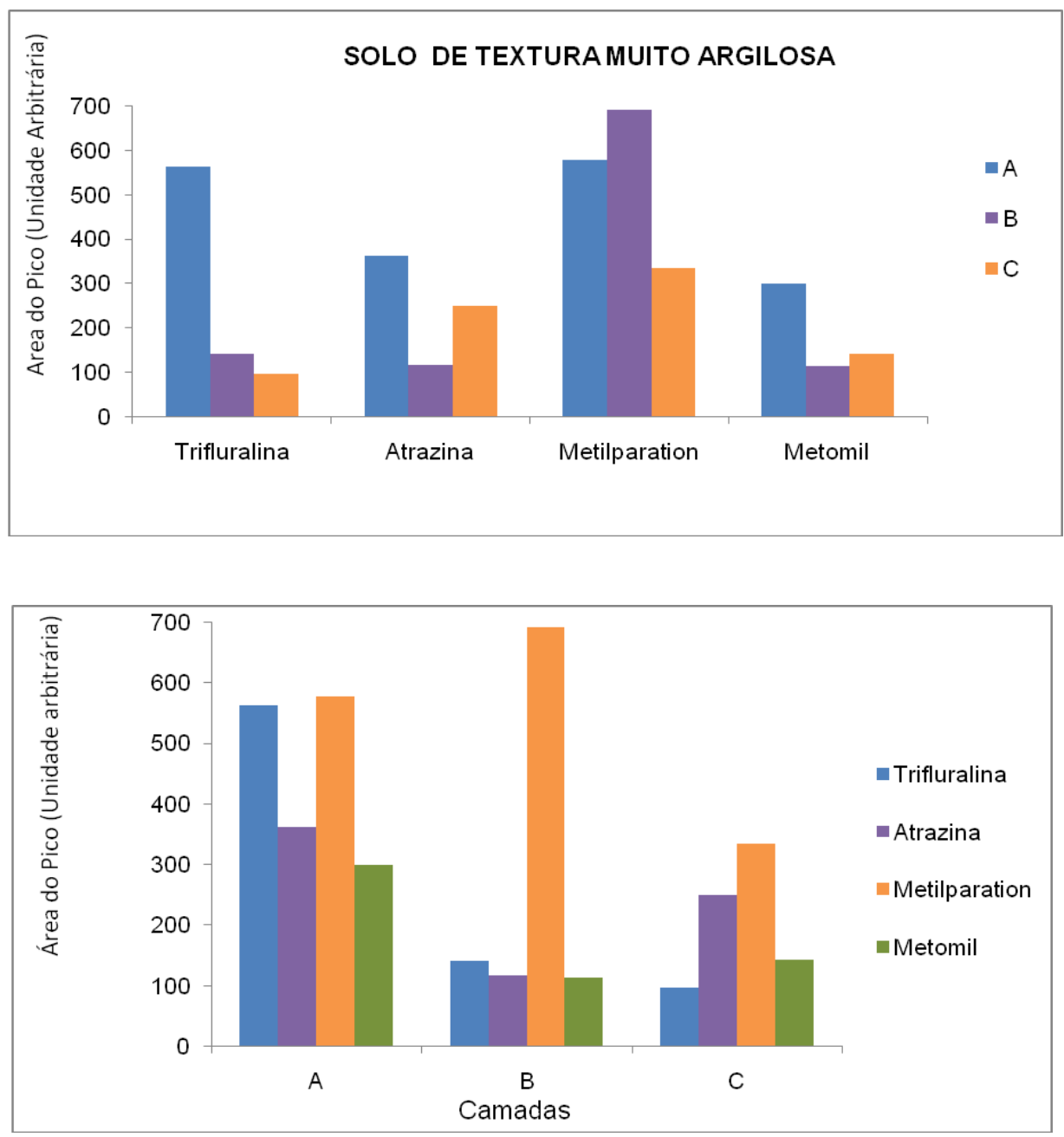

Figura 9 Perfil de distribuição por agrotóxico nas camadas e distribuição dos agrotóxicos em cada camada do solo de textura muito argilosa

Esses gráficos apresentam a área dos picos e não são as concentrações propriamente ditas, porém é proporcional a concentração, e podemos comparar os resultados dos agrotóxicos. Comparando esses resultados com os valores de TOC, que indica que ficou retido 3,9\% a mais no solo de textura Media, os resultados estão coerentes. 
A atrazina, embora tenha sido transferida em menor proporção (Tabela 6) apresentou a área do pico relativamente maior nos solos, porque a concentração inicial nas embalagens era muito mais elevada que a dos outros agrotóxicos. Apesar de sua baixa solubilidade e alta persistência, apresentou maiores concentrações na camada "A" mais úmida, nos dois tipos de solos. Segundo a literatura a atrazina, um herbicida halo aromático, tem biodegradabilidade limitada, alta pressão de vapor e alta afinidade lipídica e é considerada fazer parte da classe dos compostos persistentes no ambiente.

O metilparation que era o segundo maior pico nas embalagens e foi transferido em maior porcentagem, também estava presente nos dois solos, sendo que em maior concentração, em função da área do pico, no solo de textura muito argilosa, dessa forma pode se considerar que ficou retido no solo de textura média, devido poder de adsorção dos humos.

Alguns agrotóxicos foram lixiviados pela água, como mostrou a análise das embalagens após a lixiviação, mas não foram detectados no solo. $\mathrm{Na}$ Tabela 9 são apresentados os agrotóxicos que foram ou não extraídos de cada tipo de solo. Podem se considerar que no caso do solo de textura média ficaram ligados o clorpirifós e o metidation, muito provavelemte ter afinidade as parte orgânica do solo. No caso do solo de textura muito argilosa, ficaram ligados o clorpirifós, o metidation, o endosulfan e o triazofós. Todos são inseticidas acaricidas com maior sorção ao solo, possivelmente devido estes agrotóxicos terem $\mathrm{pH}$ menor que $\mathrm{o} \mathrm{pH}$ deste solo citado, portanto, ficaram ligados ao solo.

Essas informações são importantes porque o entendimento dos processos que afetam o transporte e comportamento dos agrotóxicos é crucial para saber seu potencial de contaminação do solo e desenvolver estratégias eficientes de remediação. Segundo a literatura, os principais fatores que afetam a sorção no solo são a hidrofobicidade do agrotóxico, o conteúdo de carbono orgânico no solo, o pH e o conteúdo mineral. 
Tabela 9. Agrotóxicos extraídos das amostras dos dois tipos de solos

\begin{tabular}{|c|c|c|}
\hline Agrotóxico & $\begin{array}{l}\text { Solo de } \\
\text { Textura Média }\end{array}$ & $\begin{array}{l}\text { Solo de } \\
\text { Textura Muito } \\
\text { Argilosa }\end{array}$ \\
\hline Trifluralin & $\operatorname{sim}$ & $\operatorname{sim}$ \\
\hline Atrazina & $\operatorname{sim}$ & $\operatorname{sim}$ \\
\hline Metilparation & $\operatorname{sim}$ & $\operatorname{sim}$ \\
\hline Clorpirifós & não & não \\
\hline Metomil & $\operatorname{sim}$ & $\operatorname{sim}$ \\
\hline Metidation & não & não \\
\hline Endosulfan & $\operatorname{sim}$ & não \\
\hline Triazofos & $\operatorname{sim}$ & não \\
\hline
\end{tabular}

\subsubsection{Distribuição dos metais nas camadas de solos}

Os resultados das análises de óxidos de metais identificados e quantificados por análises de Fluorescência de raios- $X$ nas amostras de solos de Textura média, após separação das camadas, são apresentados nas Figuras 10a, perfil de cada metal nas camadas e 10b, que apresenta o perfil de cada camada.

Esses metais apresentaram um perfil uniforme para todas as camadas do solo de textura média, mesmo após o processo de lixiviação. Desse modo pode-se considerar que não foram lixiviados pela água durante 0 tempo e condições de estudo.

Os resultados das análises de óxidos de metais identificados e quantificados por análises de Fluorescência de raios- $X$ nas amostras de solos de Textura Argilosa, após separação das camadas, são apresentados nas Figuras 11a, perfil de cada metal nas camadas e 11b, que apresenta o perfil de cada camada. Também nesse caso o perfil foi uniforme para todas as camadas. 


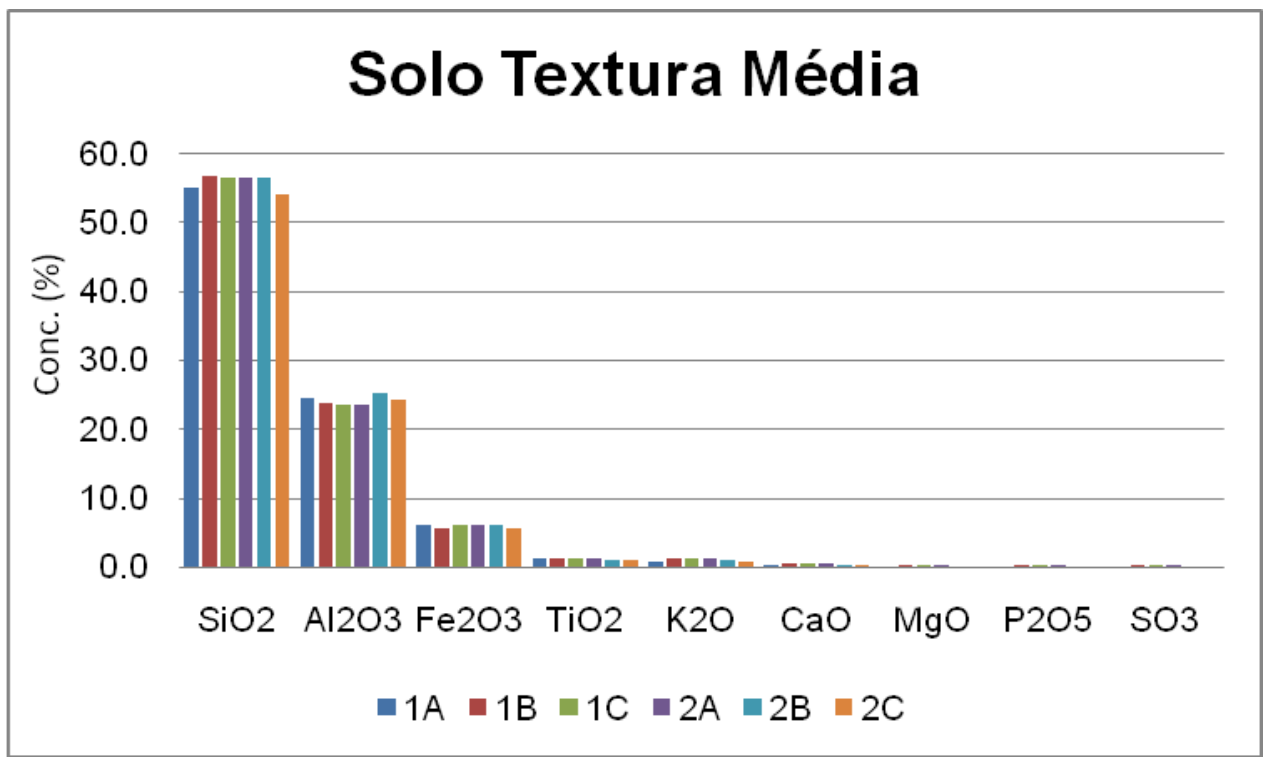

Figura 10a Perfil de concentração de cada composto metálico nas diferentes camadas do solo de textura média

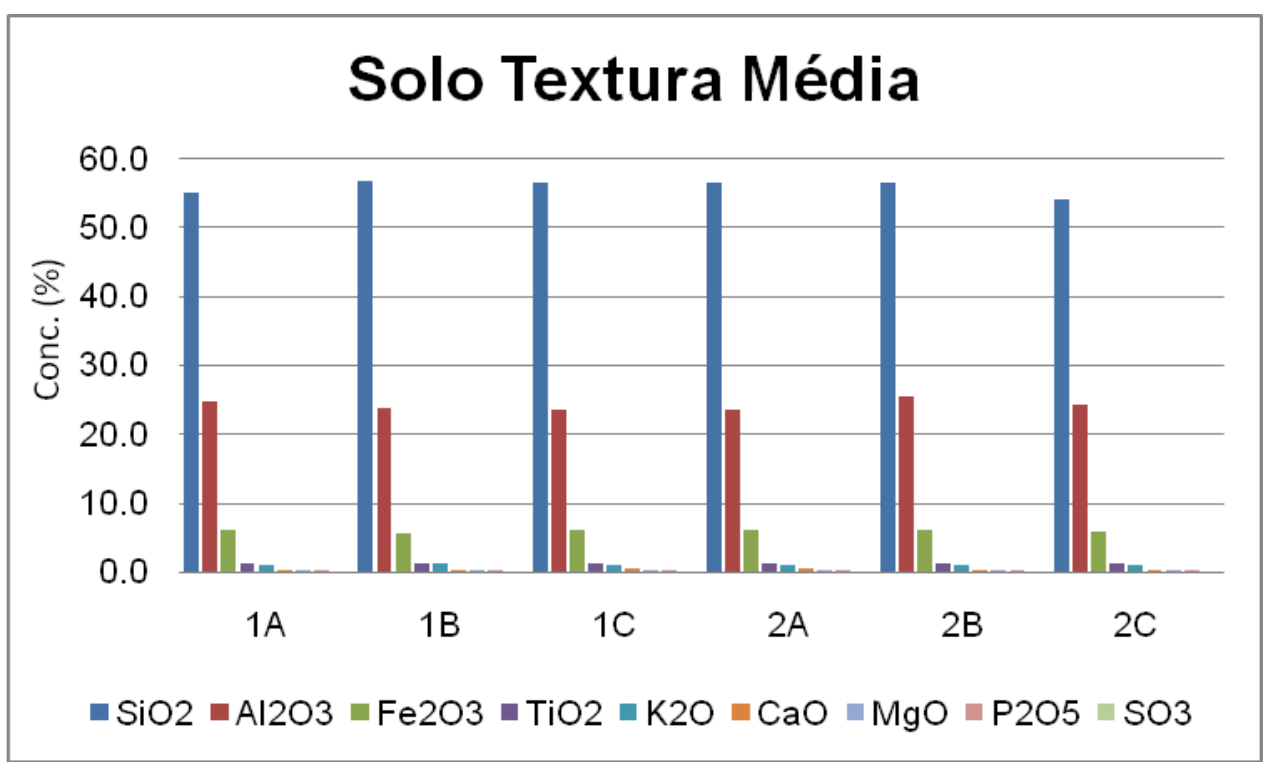

Figura 10b Perfil de cada camada do solo de textura média, considerando os diferentes óxidos metálicos. 


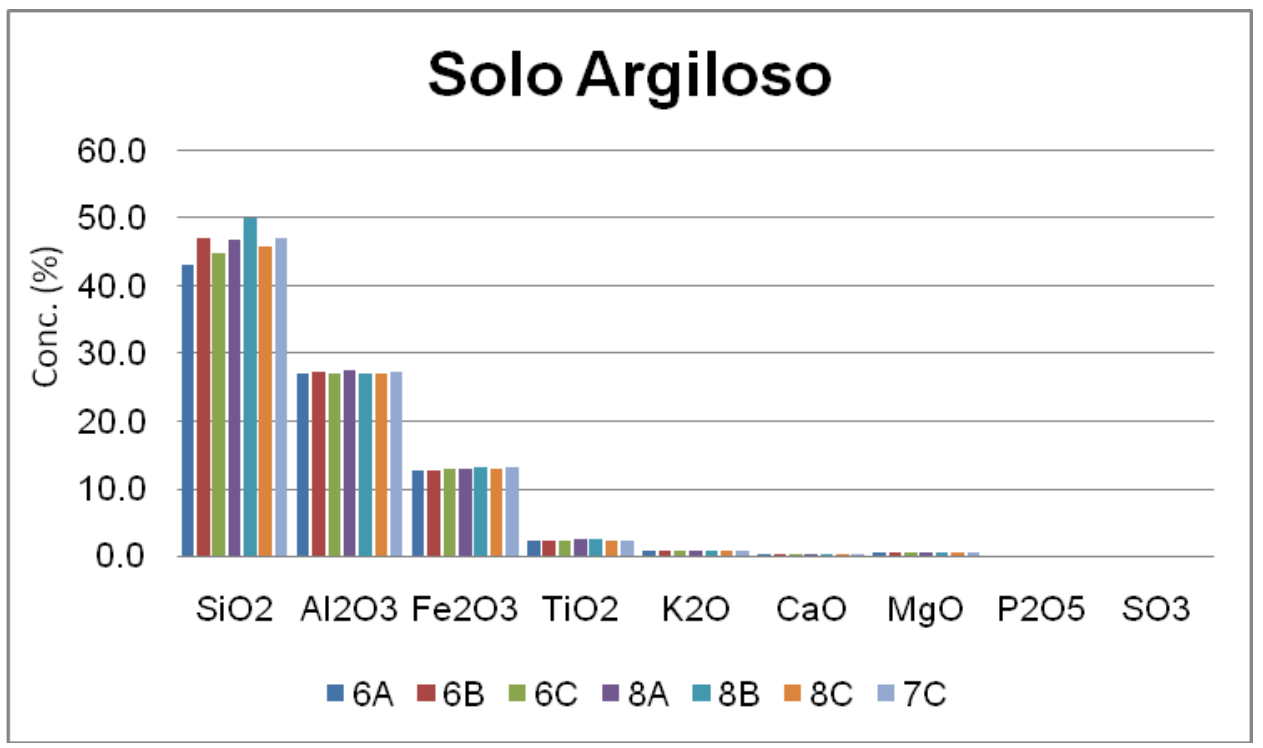

Figura 11a Perfil de concentração de cada composto metálico nas diferentes camadas do solo de textura argilosa

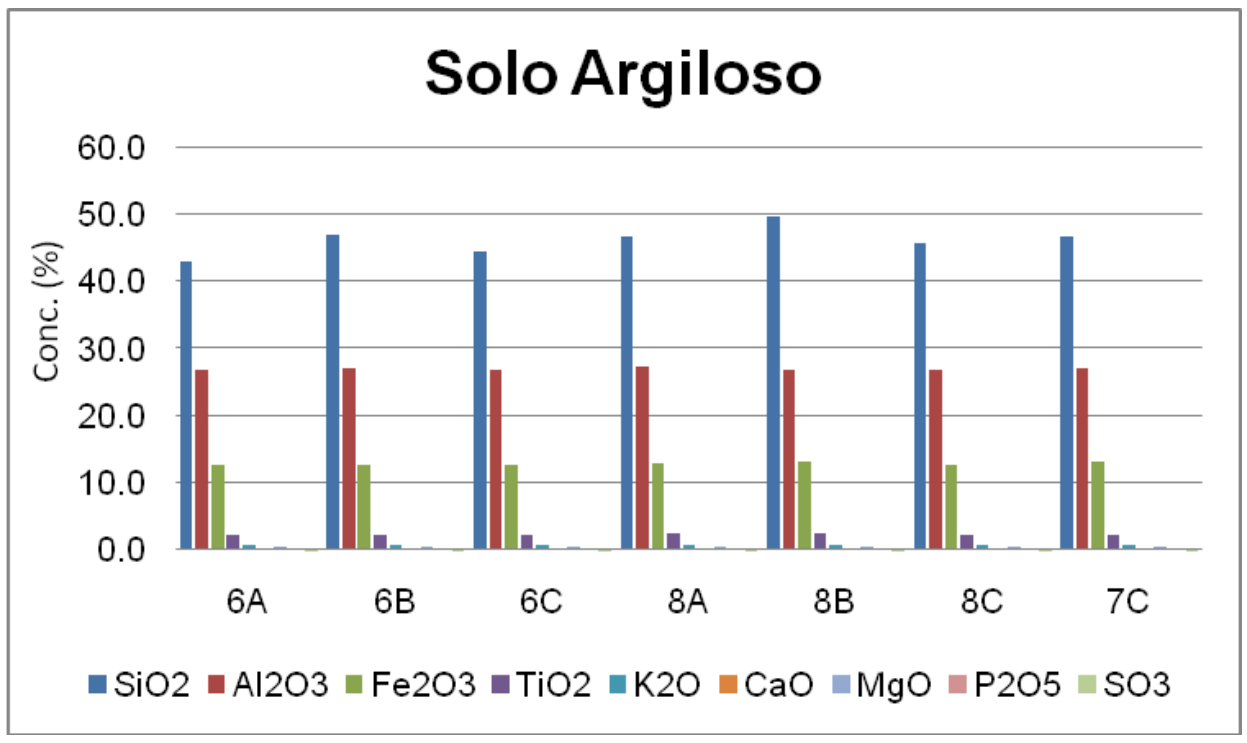

Figura 11b Perfil de cada camada do solo de textura argilosa, considerando os diferentes óxidos metálicos 


\subsection{Avaliação da eficiência do processamento por radiação gama}

Na Figura 12 é apresentada a remoção dos agrotóxicos no solo argiloso nas camadas A B e C, após irradiação gama. A ametrina e clorpirifós estão presentes em maior concentração porque foram adicionados em todas as amostras.

Na camada "A", uma dose absorvida de 5 kGy foi suficiente para remoção total de todos os agrotóxicos presentes.

$\mathrm{Na}$ camada "B" uma dose de 5 kGy removeu a totalidade de ametrina, trifluralina e triazofós. Com uma dose absorvida de cerca de $10 \mathrm{kGy}$ houve uma remoção maior que $90 \%$ dos agrotóxicos restantes, que são a atrazina, o metilparation, o clorpirifós e o metomil.

Na camada "C", cuja concentração dos agrotóxicos foi menor, o processamento por radiação gama apresentou uma eficiência menor na remoção dos agrotóxicos em geral, menos ametrina e triazofós. As menores remoções corresponderam ao metomil, à atrazina e ao metilparation.

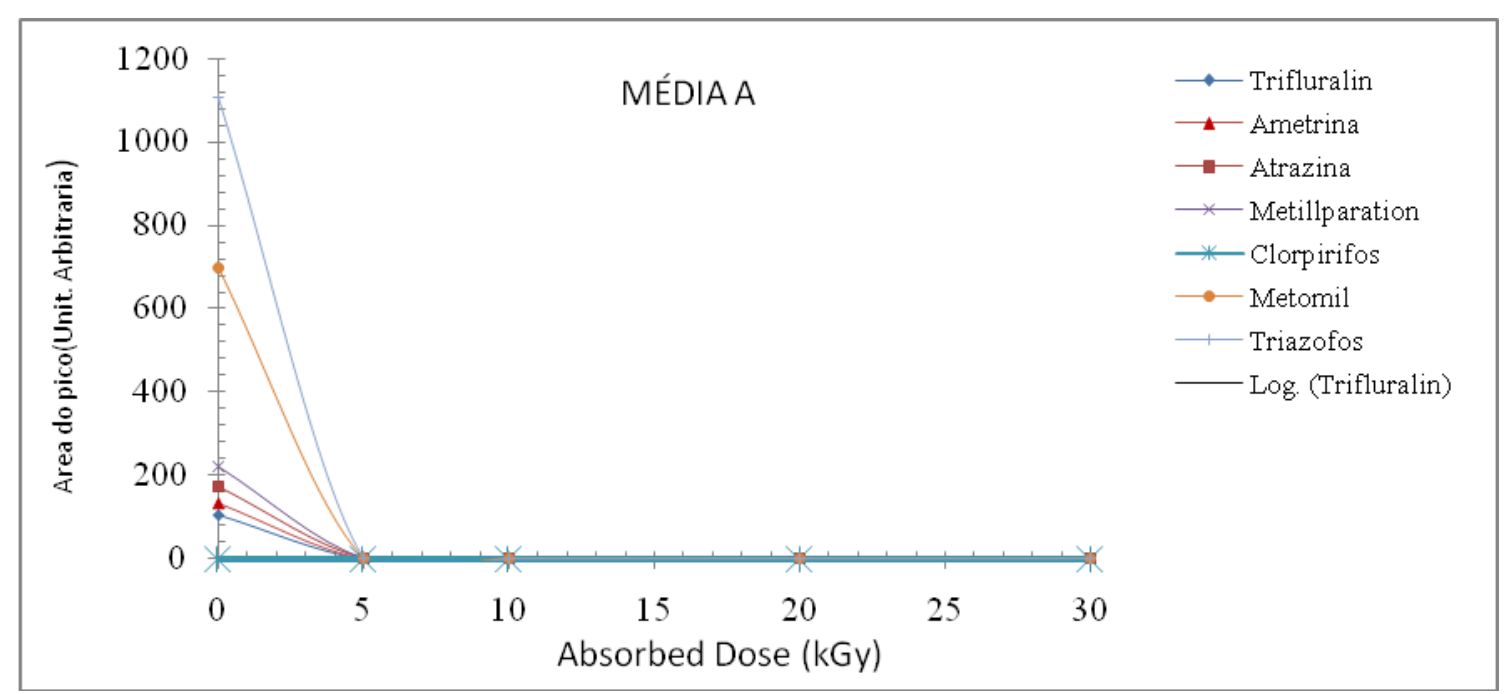



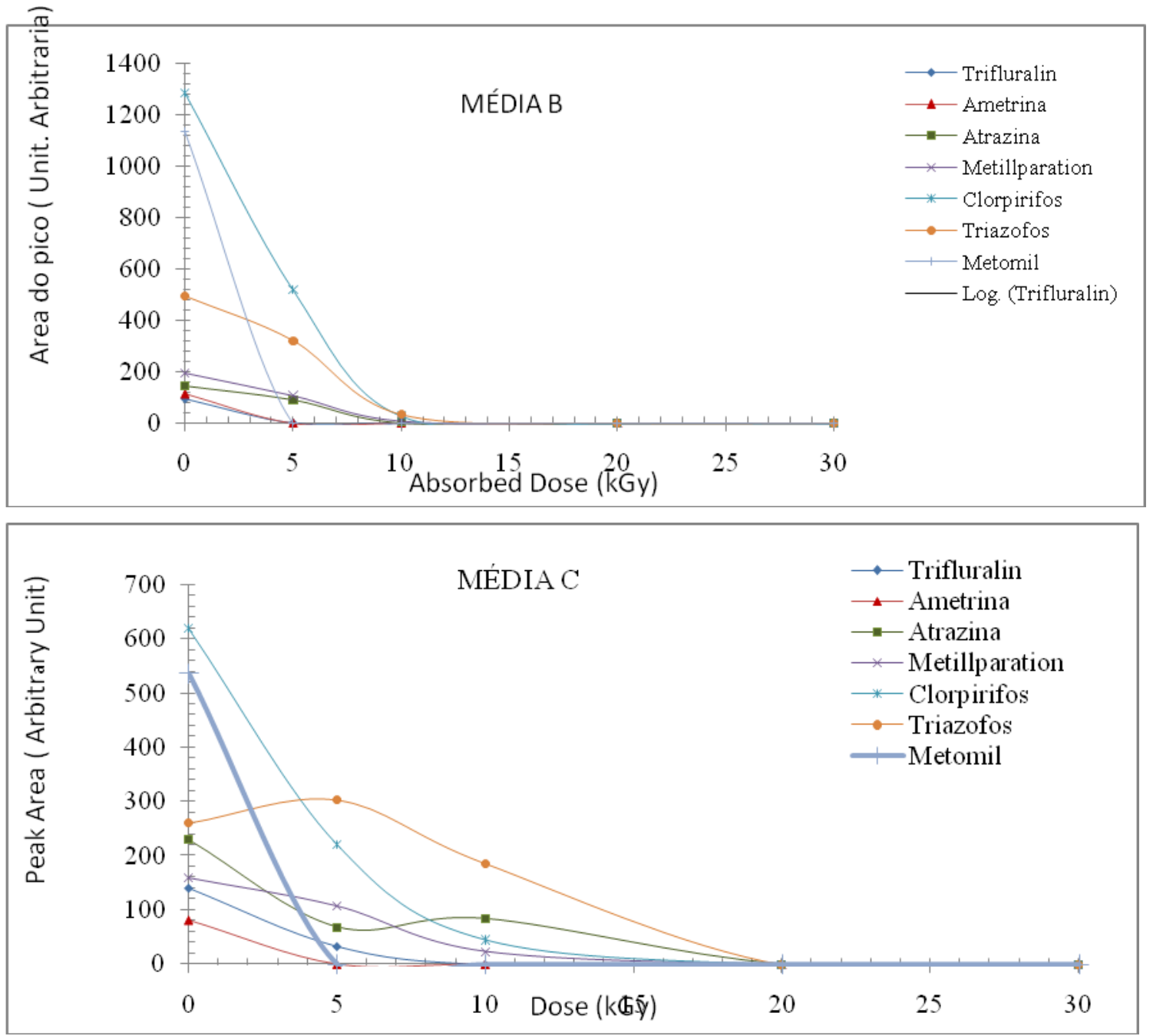

Figura 12. Remoção dos agrotóxicos do solo de textura média, após irradiação em fonte gama em diferentes doses

Na Figura 13 é apresentada a remoção dos agrotóxicos em função da dose absorvida de radiação para as diversas camadas do solo muito argiloso. Assim como no caso do solo de textura média, a remoção foi mais eficiente para as amostras com umidade mais elevada, porém neste solo a radiação foi menos eficiente que no solo de textura média.

Para uma dose absorvida de 20 kGy, foi removido $95,4 \%$ e a totalidade de clorpirifós na camada "A", mas na camada "B" foi removido 79,9\% e $88,2 \%$, respectivamente e a totalidade de atrazina, metilparation e metomil.

Na camada "C" a eficiência foi a menor sendo removido $75,9 \%$ de ametrina, $47,9 \%$ de clorpirifós e $85,9 \%$ de metilparation, com uma dose absorvida de 20 kGy. 

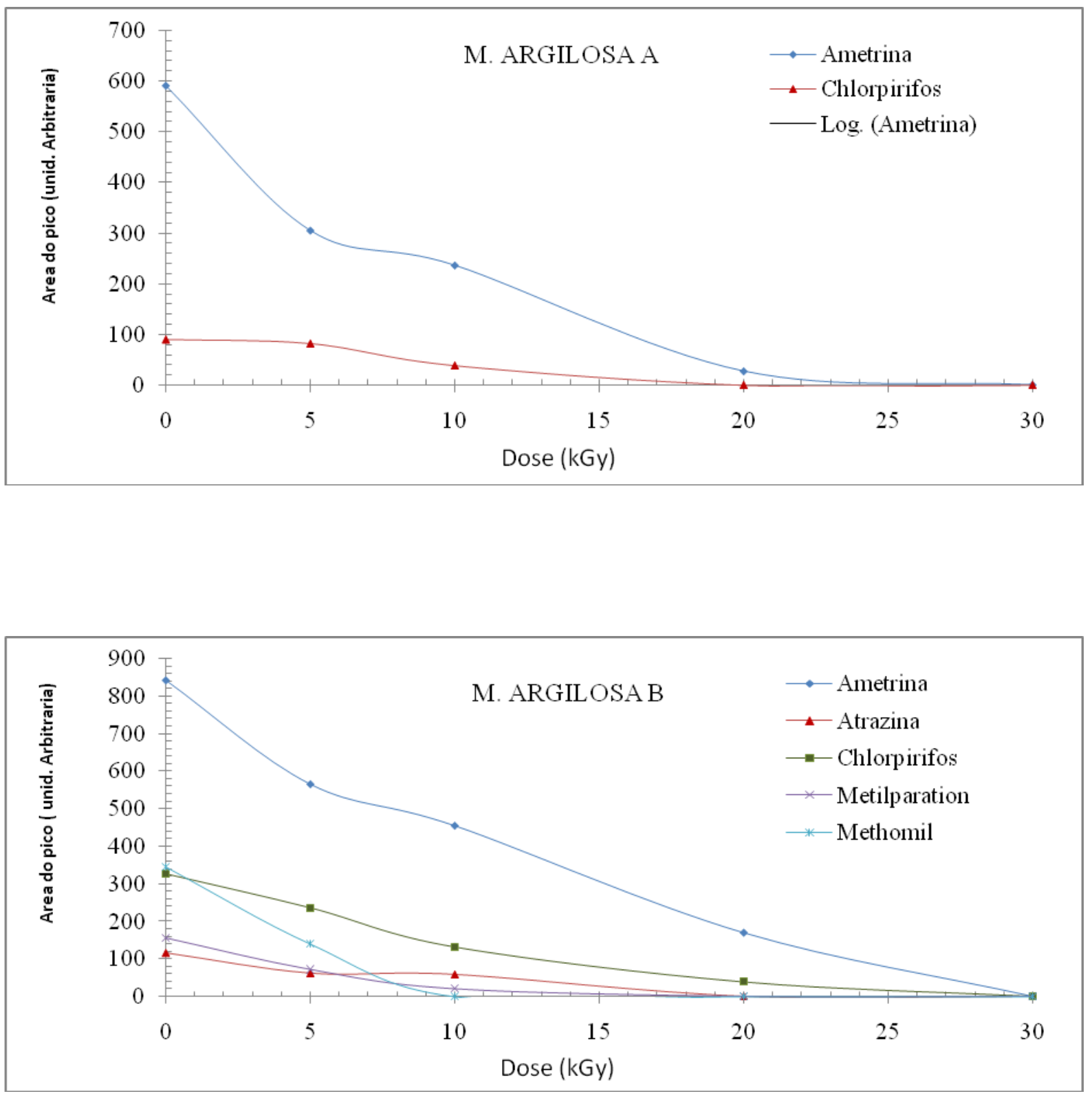


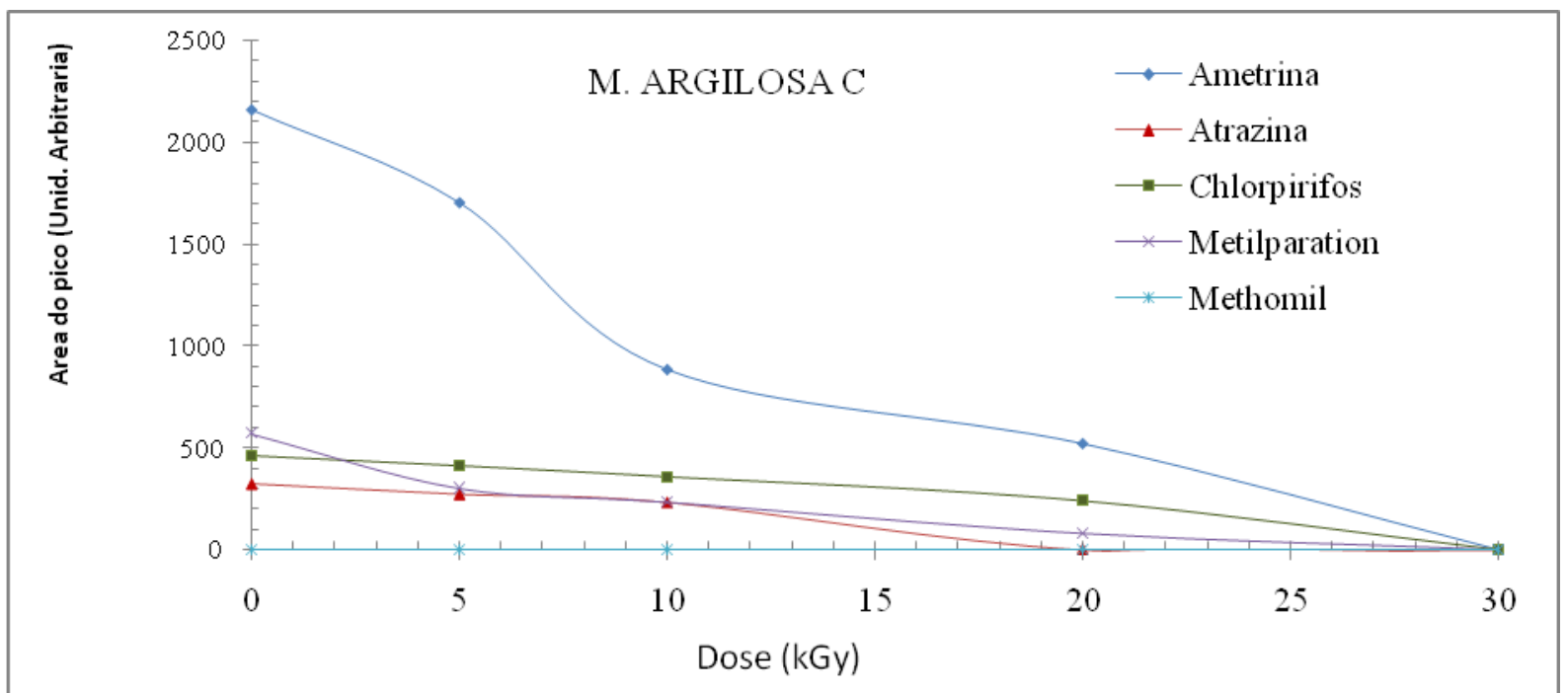

Figura 13. Remoção dos agrotóxicos do solo de textura muito argilosa, após irradiação em fonte gama em diferentes doses.

Estes resultados demonstram que a eficiência do processamento por radiação gama, embora dependa da concentração inicial, depende muito mais do teor de umidade que favorece a formação de radicais livres que atuam na oxidação dos compostos orgânicos. 


\section{Conclusões}

A avaliação de todos os resultados obtidos no presente trabalho possibilitou a elaboração de algumas conclusões e comentários:

- A lixiviação dos agrotóxicos das embalagens foi homogênea, com pequenas variações. $O$ agrotóxico que foi mais lixiviado foi o metilparation seguido pelo metomil;

- A mobilidade dos agrotóxicos nas camadas de solos depende do tipo de solo e da umidade nele existente, os agrotóxicos mais solúveis, que são os herbicidas, ficaram nas camadas mais úmidas e os inseticidas acaricidas ficaram nas camadas menos úmidas;

- Embora o solo de textura muito argilosa retivesse maior concentração de agrotóxicos, esses não foram extraídos pela mistura de solventes (hexano/diclorometano 1:1 $\mathrm{v} / \mathrm{v}$ ), provavelmente esses agrotóxicos ficaram fortemente ligados ao solo, enquanto que a extração dos agrotóxicos do solo de textura média foi mais eficiente;

- A radiação ionizante apresentou eficiência para degradação dos agrotóxicos existentes nos dois tipos de solo, mas no caso do solo de textura média, a eficiência foi mais elevada, com uma dose absorvida de $20 \mathrm{kGy}$ a totalidade dos agrotóxicos foi removida em todas as camadas. No caso do solo argiloso foi necessário uma dose absorvida maior que 30 kGy para remover a quase que a totalidade dos agrotóxicos presentes. A eficiência do processamento por radiação ionizante depende do tipo de contaminação, das características do solo contaminado e também do teor de umidade.

- No caso do solo muito argiloso não foi possível determinar se os agrotóxicos que estavam fortemente ligados foram degradados. Esta avaliação poderia ser feita utilizando-se agrotóxicos marcados $\mathrm{com}{ }^{14} \mathrm{C}$, em um futuro trabalho. 


\section{REFERÊNCIAS BIBLIOGRÁFICAS}

1. ABDEL AAL, S. E.; DESSOUKI, A. M.; SOKKER, H.H. Degradation of some pesticides in aqueous solutions by electron beam and gammaradiation. Journal of Radioanalytical and Nuclear Chemistry, v. 250, n.2, p.329-334, 2001.

2. ADRIANA D'AGOSTINHO, MARLENE FLUES. Determinação do coeficiente de distribuição $(\mathrm{Kd})$ de benzeno(a) pireno em solo por isorterma de sorção - Quimica Nova - v. 29, n. 4, p. 657-661, 2006

3. AHMAD R, KOOKANA RS, ALSTON AM, BROMILOW RH Differences in sorption behavior of carbaryl and phosalone in soils from Australia, Pakistan, and the United Kingdom. Australian Journal Soil Research, 39:893-908, 2001.

4. ALVES FILHO, J. P. Agrotóxicos e Agenda 21: sinais e desafios da transição para uma agricultura sustentável. Disponível em: $<$ http://www.iac.sp.gov.br/centros/centro\%20de\%20engenharia\%20e20\% 20\%automa\%C3\%A3\%sintag/Ajoséprado.PDF>. Acesso em: 14 fev.2007.

5. AMBRUS, A. THIER, H. P. Application of multiresidue procedures in pesticides residues analysis. Pure \& Applied Chemistry, v.58, n.7, p.1035-1062, 1986.

6. ANDRÉA, M.M. Contaminação do Solo por Agrotóxicos ; Instituto Biológico. O Biológico; vol. 60, 2000.

7. ANGELINI, G.; BUCCI, R.; CARNEVALETTI, F.; COLOSIMO, M. Radiolytic decomposition of aqueous atrazine. Radiation Physics and Chemistry, v.59, n.3, p.303-307, 1998.

8. ARMAS, E. D. et al. Uso de agrotóxicos em cana-de-açúcar na Bacia do Rio Corumbataí: o risco da poluição hídrica. Química Nova, v.28, n.6, p.975-982, 2005.

9. ASSOCIAÇÃO BRASILEIRA DE NORMAS TÉCNICAS NBR10004 (ABNT,1987

10.ASSOCIAÇÃO BRASILEIRA DE NORMAS TÉCNICAS NBR10.005 (ABNT,1987)

11.ASSOCIAÇÃO BRASILEIRA DE NORMAS TÉCNICAS NBR 13600 (ABNT,1987) 
12.ASSOCIAÇÃO NACIONAL DE DEFESA VEGETAL. Manual de uso correto e seguro de produtos fitossanitários/ agrotóxicos. Disponível em: $<$ http://www.andef.com.br>. Acesso em set. 2008.

13.BACHMAN, S.; GIESZCZYNSKA, J. Effect of gamma irradiation on pesticide residue in food products. In IAEA ed. Agrochemicals: Fate in Food and Environment. Vienna, International Atomic Energy Agency, 1982, p.313-315. Vienna: IAEA, 1982.

14.BALINOVA, A. Strategies for chromatographic analysis of pesticide residues in water. Journal of Chromatography A, v.754, p.125-135, 1996.

15.BELLUCK, D. A.; BENJAMIN, S. L.; DAWSON, T. Groundwater contamination by atrazine and its metabolites: risk assessment, policy and legal implications. In: SOMASUNDARAM, L.; COATS, J. R. (Ed.). Pesticide transformation products: fate and significance in the environment. Washington: American chemical Society Press, p.254-273, 1991. (Symposium Series, 459).

16.BOLLAG, J. M.; LIU, S. Y. Pesticides in the Soil Environment: Process, Impacts and Modeling. In: CHENG, H. H. (Ed). Soil Science Soc. Am: Madison, p. 169, 1990.

17.BRADY, N. C. The nature and properties of soils. Trad. Antonio B. Figueiredo $\mathrm{F}^{\circ} .7^{\mathrm{a}}$ ed. Rio de Janeiro, Freitas Barros, 1989.

18.BRAILE, P. M.; CAVALCANTI, J. E. W. A. Manual de tratamento de águas residuárias e industriais. São Paulo, Cetesb, p.1-107, 1979.

19.BUSS, A.; GLÓRIA, N. A.; JACINTO, O. A. Viabilidade do uso de herbicidas em mistura com vinhaça para o controle de plantas daninhas em soqueiras de cana-de-açúcar. Planta Daninha, v.2, p.49-56, 1978.

20.CAMARGO, O. A.; MONIZ, A. C.; JORGE, J. A.; VALADARES, J. M. Métodos de análise química, mineralógica e física de solos do IAC. Campinas: Instituto Agronômico de Campinas, (IAC Publicação 106), 1986.

21.CAMARGO, O.A. \& ALLEONI, L.R.F. Compactação do solo e o desenvolvimento das plantas. Piracicaba, Escola Superior de Agricultura Luiz de Queiroz, 132p. 1997.

22.CARRILHO, E.; TAVARES, M. C. H.; LANÇAS, F. M. Fluidos supercríticos em química analítica. Química Nova, v.29, n.4, p.790-795, 2006.

23.CHAIM, A. et al. Manejo de agrotóxico e qualidade ambiental: manual tecnico. Jaguariúna: Embrapa Meio ambiente, 1999. 
24.COROCHER, R. A.; WIENDL, F. M. Efeitos da radiação gama do cobalto-60 em pirimifós-metil e malation. Ecossistema, 8, p.5-8, 1983.

25. COSTA, M. A. Biodegradação de 14C-ametrina em areia quartzosa com adição de palha de cana e solo rizosférico. 1992. Dissertação (Mestrado) - Escola Superior de Agricultura Luiz de Queiroz, Piracicaba.

26.COUTINHO, C.F.B.; TANIMOTO, S.T.; GALLI, A.; GARBELLINI, G.S.; TAKAYAMA, M.; AMARAL, R.B.; MAZO, L.H.; AVACA, L.A.; MACHADO, S.A.S. Pesticidas: mecanismos de ação, degradação e toxidez. Ecotoxicologia e Meio Ambiente, v.15, p.65-72, 2005.

27.CRUCIANI, D.E.; BAPTISTA, G.C.; CHRISTOFFOLETI, P.J.; MINAMI, K.; Comportamento de herbicida em solo de várzea com drenagem subterrânea. Science Agriculture, v.53, 2-3. Piracicaba, 1996.

28.CURRY D. R, MINCHER B. J. The status of PCB radiation research; prospects for waste treatment in nonpolar solvents and soil. Radiation Physics and Chemistry, v.56: p.493-502, 1999.

29.DE LUNA, A. J.; DE SALES,, L. T.; DA SILVA, R. F. Agrotóxicos: responsabilidade de todos (uma abordagem da questão dentro do paradigma do desenvolvimento sustentável). Jaboticabal, Unesp, 2004. Disponível em: <http://www.prt6.gov.br/ forum/downloads/ artigo 1 Adeilson. doc >. Acesso em 25 fev.2007.

30.DUARTE, C. L.; ANDRADE, D. C.;MELO, R. P.; NAGATOMI, H. R.; MORI, M. N. Decontamination of ametryne HDPE packaging using electron beam accelerator. Radiation Physics and Chemistry, 2009.

31.DUARTE, C. L.; GERARDO, L. L.; JUNIOR, O. A. P.; BORRELY, S. I.; SATO, I. M.; SAMPA, M. H. O. Treatment of effluent from petroleum production by electron-beam irradiation. Radiation Physics and Chemistry, v.71, p.445-459, 2004.

32.DUARTE, C. L.; MORI, M. N.; YASKO, K.; OIKAWA, H.; SAMPA, M. H. O. Decontamination of pesticide packing using ionizing radiation. Radiation Physics Chemistry, v.26, p.1885-1889, 2007.

33.DUARTE, C. L.; SAMPA, M. H. O.; RELA, O. H.. P. R.; SILVEIRA, C. G. Advanced oxidation process by electron-beam-irradiation induced decomposition of pollutants in industrial effluents. Radiation Physics and Chemistry, v.63, p.647-651, 2002.

34.EMPRESA BRASILEIRA DE AGROPECUÁRIA, EMBRAPA. Manual de métodos de análise de solo. Sociedade Brasileira de Ciência do Solo, Rio de Janeiro, 1979. 
35. EMPRESA BRASILEIRA DE AGROPECUÁRIA, EMBRAPA. Manual de métodos de análise de solo. Centro Nacional de Pesquisa de Solos, Rio de Janeiro, 1997. $2^{\mathrm{a}}$ ed., 212 p.

36.FÁBIO PRATA. Comportamento do Glifosato no Solo e Deslocamento Miscível de Atrazina - Tese (Doutorado) - 2002 Universidade de São Paulo. ( SORÇÃO pH)

37.FREIRE, R.S., PELEGRINI, R., KUBOTA, L.T., DURAN, N. E ZAMORA, P.P. Novas tendências para o tratamento de resíduos industriais contendo espécies organocloradas. Quimica Nova, v.23, p.504-511, 2000.

38.GARRETT, B. C., DIXON, D.A., CAMAIONI, D.M., CHIPMAN, D. M., JOHNSON, M.A., ZWIER, T. S. Role of water in electron-initiates process and radical chemistry: issues and scientific advances. Chemical Review, v.105, p.355-389, 2005

39.GEHRINGER,P.; ESCHWEILER, H.; SZINOVATZ, W.; FIEDLER, R.; STEINER, R.; SONNECK, G. Radiation-induced $\mathrm{OH}$ radical generation and use for ground remediation. Radiation Physics and Chemistry, v. 42 (4-6), p.711-714, 1993.

40.GETOFF, N. Radiation-induced degradation of water pollutants- state of the art. Radiation Physics and Chemistry, v.47 (4), p.581-593, 1986.

41.GHISELLI, G. Remediação de solos contaminados com pesticidas organoclorados utilizando reagente de Fenton. Dissertação de mestrado. IQ-UNICAMP. Campinas, 2001

42.GRAY, K. A. E HILARIDES, R. J. Radiolytic treatment of dioxin contaminated soils. Radiation Physics and Chemistry. 46, p.10811084, 1995.

43.HAJSLOVÁ, J. Pesticides. In: MOFFAT, C.F.; WHITTLE, K.J. (eds). Environmental Contamination in Food. London, Academic Press, 1999, pp.215-272.

44.HAMAKER, J.W; THOMPSON, J.M. Adsorption. In: GORING CAI, HAMAKER J.W. (eds) Organic chemicals in the soil environment. Marcel Dekker Inc. New York, pp. 49-144, 1972.

45.HASSETT, J.J.; MEANS, J.C.; BANWART, W.L.; WOOD, S.G. Sorption properties of sediments and energy-related pollutants. EPA Report 600/3-80-041, 1980.

46.HIGARASHI, M.M.; JARDIM, W.F. Remediation of pesticide contaminated soil using TiO2 mediated by solar light. Catalysis Today. V.76, p.201-207, 2002. 
47.HILARIDES, R. J.; GRAY, K. A. Radiolytic degradation of 2, 3, 7, 8-TCDD in artificially contaminated soils. Environmental Science Technology, 28, 2249-2258, 1994.

48. INSTITUTO NACIONAL DE PROCESSAMENTO DE EMBALAGENS VAZIAS. Destinação final de embalagens vazias de produtos fitossanitários. Disponível em: <http://www.inpev.gov.br> . Acesso em out. 2008.

49. ISABELLA ANNA MEZZARI. Utilização de Carvões adsorventes para o tratamento de efluentes contendo pesticidas - Dissertações (Mestrado) -2002- Universidade Federal de Santa Catarina. (PERSISTENCIA)

50.JAVARONE, R.C.; TALAMONI, J.; LANDGRAF, M. D.; REZENDE, M. O. LUCHINI, L. C. Estudo da degradação de lindano em solução aquosa através de radiação gama. Química Nova, v.14, p.237-239, 1991.

51.KARICKHOFF, S. W.; BROWN, D.S; SCOTT, T.A. Sorption of hydrophobic pollutants on natural sediments. Water Research, v.13, p. 241-248, 1979.

52.KIEH, JE. Manual de edafologia: Relação solo-planta - São Paulo, Ed. Agronomica leves, pag. 264, 1979. Humífero

53.KOUSTAS, R.N.; FISCHER, D. Review of separation technologies for treating pesticide-contaminated soil. Journal Air \& Waste Management Association, v.48, p.434-440, 1998.

54.KUBESH, K.; ZONA, R.; SOLAR, S.; GEHRINGER, P. Degradation of catechol by ionizing radiation, ozone and the combined process ozoneelectron-beam. Radiation Physics and Chemistry, v.72, p.447-453, 2005.

55.LÊ PAUDER, D. Agroquímica: adubos e produtos sanitários. Contato, v.28 (6), p.16-20, 1994.

56.LEGRINI, O., OLIVEROS, E.; BRAUN, A. M. Photochemical processes for water treatment. Chemical Review, v.2 (92), p.671-698, 1993.

57.LIPPOLD, P.C.; CLEERE, J.S.; MASSEY, L.M.; BOURK, J.B.; AVENS, A.W.; Degradation of insecticides by cobalt-60 gamma radiation. Journal Economical Entomology, v.62, p.1509-1510, 1969.

58. LUCHINI, L. C. Degradação do inseticida paration em diversas matrizes ambientais por meio da radiação ionizante gama do cobalto-60. 1995. Tese (Doutorado) - Instituto de Química de São Carlos, São Carlos. 
59.LUCHINI, L. C.; PERES, T. B.; RESENDE, M. O. O. Degradation of insecticide paration in methanol by gamma-irradiation. Journal of Radioanalytical and Nuclear Chemistry. v.241 (1), p.191-194, 1999.

60.MARCHESE, L. Sorção/dessorção e lixiviação do herbicida ametrina em solos canavieiros tratados com lodo de esgoto. 2007. Dissertação (Mestrado) - Centro de Energia Nuclear na Agricultura, Piracicaba.

61.MORI, M. N. Descontaminação de embalagens descartadas clorpirifós utilizando o processo de oxidação avançada por radiação ionizante. 2006 Dissertação (Mestrado) - Instituto de Pesquisas energéticas e Nucleares, São Paulo.

62.MORI, M. N.; SAMPA, M. H. O; DUARTE, C. L. Study of the degradation of chlorpyrifos by ionizing radiation. Journal of Radioanalytical and Nuclear Chemistry, 270 (1): 99-102, 2006.

63.MUSUMECI, M. R. Microbiologia do Solo. In TSAI, S. M.; NEVES, M. C. P. (eds). Sociedade Brasileira do Solo: Campinas, 341p, 1992

64.NAM, P. Solvent extraction and tandem dechlorination for decontamination of soil. Chemosphere, v.43, p.485-491, 2001.

65.PERES, T. B.; PAPINI, S.; MARCHETTI, M.; NAKAGAWA, L. E.; MARCONDES, M. A.; ANDRÉA, M. M.; LUCHINI, L. C. Métodos de extração de agrotóxicos de diversas matrizes. Arquives Institutional Biology, v.69 (4), p.87-94, 2002.

66.PODZOROVA, E. A. New developments in radiation-chemical technology of sewage treatment. Radiation Physics and Chemistry, v.46 (4-6), p.1129-1132, 1995.

67. QUEIROZ, S. C. N. Determinação de multirresíduos de pesticidas em água por cromatografia líquida de alta eficiência com ênfase em detecção por espectrometria de massas e novos sorventes para extração em fase sólida. 2001. Tese (Doutorado) - Universidade Estadual de Campinas, Campinas.

68.QUEIROZ, S. C. N.; LAZOU, K.; SANDRA, P.; JARDIM, I. C. S. F. Determination of pesticides in water by liquid chromatography (electrospay ionization) - mass spectrometry (LC - ESI - MS). Pesticidas: Ecotoxicologia e Meio Ambiente, v.14, p.53-60, 2004.

69. ROBERTS, T. R. ET AL. Metabolic pathways of agrochemicals. Part 1: Herbicides and plant growth regulators. London: The Royal Society of Chemistry. 1998.

70.SCANDAR GASPERAZZO IGNATUS. Solos Tropicais: Proposta de Índice Classificatório. Solos e Rochas, São Paulo, 14, 89 - 93, 1991. 
71.SEMPLE, K.T.; REID, B.J.; FERMOR, T.R. Impact of composting strategies on the treatment of soils contaminated with organic pollutants. Environmental Pollution, v. 112, p.269-283, 2002

72.SINDICATO NACIONAL DA INDÚSTRIA DE PRODUTOS PARA DEFESA AGRÍCOLA. Disponível em : http://www.sindag.com.br .Acesso em outubro,2008.

73.UNITED STATE DEPARTAMENT OF AGRICULTURE SOIL STAFF USDA Soil Taxonomy: a Basic System of Soil Classification for Making and Interpreting Soil Surveys. Washington, 1975, 754 p.

74.VEL LEITNER, N. K.; BERGER, P.; GEHRINGER, P. Gamma-irradiation for the removal of atrazine in aqueous solution containing humic substances. Radiation Physics and Chemistry, v.55, n.3, p.317-322, 1999.

75.VILLA, R. D.; TROVÓ, A.G.; NOGUEIRA, R.F.P. Environmental implications of soil remediation using the Fenton process. Chemosphere, v.7, p.43-50, 2008.

76.YAK, H.K.; MINCHER, B. J.; CHIU, K.; WAI, C. M. Supercritical fluid extraction/ $\gamma$-radiolysis of PCBs from contaminated soil. Journal Hazardous Materials, v.69, p.209-216, 1999.

77.YU, X.; WANG, X.; BARTHA, R.; ROSEN, J. Supercritical fluid extraction of coal tar contaminated soil. Environmental Science Technology, v.24, p.1732-1738, 1990.

78.ZACHEIS, G. A., GRAY, K. A. E KAMAT, P. V. Radiolytic reduction of hexachlorobenzene in surfactant solutions: A steady-state and pulse radiolysis study. Environmental Science Technology, v.34, p.34013407, 2000.

79.ZONA, R.; SOLAR,S. Oxidation of 2,4-dichlorophenoxyacetic acid by ionizing radiation: degradation, detoxication and mineralization. Radiation Physics and Chemistry, v.66 (2), p.137-143, 2003. 